\title{
How to Stop Harassment: Professional Construction of Legal Compliance in Organizations
}

\section{Citation}

Dobbin, Frank, and Erin L. Kelly. 2007. How to stop harassment: Professional construction of legal compliance in organizations. American Journal of Sociology 112, no. 4: 1203-1243.

\section{Published Version}

http://dx.doi.org/10.1086/508788

\section{Permanent link}

http://nrs.harvard.edu/urn-3:HUL.InstRepos:3228852

\section{Terms of Use}

This article was downloaded from Harvard University's DASH repository, and is made available under the terms and conditions applicable to Other Posted Material, as set forth at http:// nrs.harvard.edu/urn-3:HUL.InstRepos:dash.current.terms-of-use\#LAA

\section{Share Your Story}

The Harvard community has made this article openly available.

Please share how this access benefits you. Submit a story.

Accessibility 


\title{
How to Stop Harassment: Professional Construction of Legal Compliance in Organizations $^{1}$
}

\author{
Frank Dobbin \\ Harvard University \\ Erin L. Kelly \\ University of Minnesota
}

\begin{abstract}
Most employers installed sexual harassment grievance procedures and sensitivity training by the late 1990s. It was personnel experts, not courts, legislatures, or lawyers, who promoted these antiharassment strategies, drawn from the profession's tool kit. Personnel succeeded because it was executives, not public officials, who defined professional jurisdiction, and executives proved susceptible to personnel's argument that bureaucratic routines could reduce legal risk. With each landmark in harassment law, more employers adopted the grievance procedures personnel advocated despite negative reviews from lawyers. Employers who consulted personnel experts were more likely to join the bandwagon; those who consulted lawyers were less likely. The case holds lessons for the evolution of professions, because executives play an increasing role in defining professional jurisdiction.
\end{abstract}

Personnel managers and lawyers began to debate how employers could protect themselves from liability for sexual harassment in the late 1970s. Personnel experts recommended two arrows from their professional quiver, grievance procedures and training programs. Many lawyers ar-

\footnotetext{
${ }^{1}$ We are grateful to the Alfred P. Sloan Foundation and a National Science Foundation Dissertation Improvement Grant for funding, to the Survey Research Center at the University of Maryland for conducting the survey for us, to Alexandra Kalev and Randi Ellingboe for research assistance, and to Susan Bisom-Rapp, Lauren Edelman, Heather Haveman, Abigail Saguy, Vicki Schultz, Melissa Williams, and the AJS reviewers for helpful comments. Direct correspondence to Frank Dobbin, Department of Sociology, Harvard University, 675 William James Hall, Cambridge, Massachusetts 02138. E-mail: dobbin@wjh.harvard.edu
}

(C) 2007 by The University of Chicago. All rights reserved. 0002-9602/2007/11204-0006\$10.00 
gued that no bureaucratic fix would suffice, and some pointed out that grievance procedures might give employers knowledge that would make them liable for harassment. Neither grievance procedures nor training provided much legal protection until 1998, when the Supreme Court ruled that they could be used by defendants in certain kinds of cases. By then 19 out of 20 big employers had harassment grievance procedures, and 7 out of 10 provided training. More employers offered grievance procedures than unpaid maternity leaves, which were explicitly required by federal law. We investigate how two professions constructed the threat of sexual harassment and the appropriate organizational response to it during a period when case law and social norms were changing rapidly.

As the formal organization has absorbed more and more of social life, jurisdictional disputes between professional groups increasingly play out before executives rather than public officials. Professions win jurisdiction not through state licensure, but by popularizing the management practices they favor. Our theoretical contribution concerns the professional strategies that work best before the audience of executives. Before state officials, the classic liberal professions won jurisdiction by demonstrating expertise and knowledge. Before organizational executives, successful professional claims look different. Executives are concerned with reducing risks that can threaten their livelihood, yet they often judge the success of a new organizational initiative by whether it runs smoothly and has predictable costs, rather than by whether it meets the original goals (Van de Ven et al. 1999). Expert groups that catalyze concern about risk and provide bureaucratic solutions can thus trump those that claim superior expertise. In this case, personnel's ready bureaucratic remedy trumped lawyers' counsel, which was to consult attorneys at the first sign of harassment. In the end, personnel won government sanction by convincing enough executives, rather than convincing executives by winning government sanction.

Professional modus operandi explains the divergent advice proffered by personnel and legal experts. Personnel's advice was based in the field's tradition of building bureaucracy, a tradition dating to the 1930s when personnel experts and lawyers divided up the turf of labor relations. Attorneys' advice was based in their traditional deference to case law and their technology of case consultation. When harassment came on stage, the two professions revived their old labor relations roles.

We bring two types of evidence to bear on the question of how personnel and legal experts shaped employer antiharassment measures. First, we describe the advice offered by these professions as sexual harassment law changed. We also summarize a systematic review of the articles published in personnel and legal journals between 1977 and 1997, where we find that personnel articles often mentioned grievance procedures and training 


\section{Legal Compliance}

as compliance strategies, while legal articles rarely mentioned training and often mentioned grievance procedures only to argue that they would not protect employers. Second, our quantitative analyses of the spread of sexual harassment grievance procedures, broader "general" harassment procedures, and antiharassment training programs among 389 employers between 1965 and 1997 confirm two interesting hypotheses. First, each time a legal landmark seemed to ratchet up the risk of a harassment lawsuit, executives became significantly more likely to follow the early advice of personnel experts (and less likely to heed warnings from lawyers). Increases in the perceived legal risk enabled personnel experts to trump the obvious expertise of lawyers, who gradually came around themselves. Second, the professions had direct influence through their consultative roles. Executives who consulted legal experts were less likely to install harassment procedures; those who consulted personnel were more likely.

\section{THE PROFESSIONS IN ORGANIZATIONS}

The classic literature on the professions focused on how particular groups won public confidence and credentials (Friedson 1975; Sarfatti-Larsen 1977; Starr 1982). Andrew Abbott revolutionized the field with a systems perspective on professionalization projects, attentive to the contending groups that vie for authority in a given domain. In ancien regime France, Abbott (1988, p. 157) observes, the groups competing for work as healers included "physicians, surgeons, pharmacists, 'empirics,' operators, spagiristes, and . . . the various members of the clergy." Most relevant to the case at hand, Abbott finds different patterns of contention over legal authority in Britain, where lawyers were scarce and hence faced territorial invasion from adjacent groups (accountants, justices of the peace, etc.) and the United States, where lawyers were not in short supply. Whereas Abbott paints a broad historical picture of professional contests, we explore how expert groups have recently vied for authority in a new venue, the executive suite.

Institutionalists have examined how experts seek to establish authority within organizations (Dobbin and Sutton 1998; Fligstein 1990), but they have not much explored what happens when two groups vie for authority over the same issue (but see Edelman, Abraham, and Erlanger 1992; Stryker 2000). We chart the most recent episode in a longstanding struggle between personnel and law over compliance with labor law. It stands to reason that in matters of law, executives would listen to lawyers. Personnel succeeded by appealing to executives' concern with risk, and preference for stable bureaucratic compliance strategies over lawyers' one-case-ata-time approach. Managerial perceptions of legal risk were heightened 
American Journal of Sociology

by the ambiguity of civil rights law in general and harassment law in particular (Edelman 1992). Personnel experts exaggerated the risk faced by the average employer and exaggerated the legal protection to be found in grievance procedures and training, as we show below. Yet their strategies were widely adopted and eventually vetted by the Supreme Court.

The roots of the personnel and legal professions explain their different initial responses to harassment law. From the 1920s the personnel profession developed expertise in employee placement and labor relations around a core technology of bureaucratization (Brandes 1976; Brody 1980). After the Wagner Act of 1935 empowered unions, personnel experts negotiated union contracts alongside labor lawyers and went on to implement the grievance procedures, seniority systems, job classification schemes, and pension programs written into those contracts. Later, personnel matched these bureaucratic systems in large nonunion firms (Kochan, Katz, and McKersie 1986; Selznick 1969).

The legal profession had flourished earlier; with the rise of the modern corporation, lawyers set up shop as independent professionals with a technology of case consultation (Abbott 1988, p. 247). Lawyers claimed the singular ability to offer precedent-based advice that would stand up in court. Even after lawyers joined the payroll as house counsel (Leicht and Fennell 1996) they acted as consultants on individual cases and contracts-they did not design bureaucratic systems for managing legal issues (Nelson and Nielsen 2000).

Their different professional modus operandi shaped the solutions to the problem of harassment that personnel experts and lawyers envisioned. Comparing how lawyers and scientists behave in the same organization, Robin Stryker (2000, p. 196) finds that different professional groups are "trained and socialized to promote the rules" and organizational problemsolving approaches "that best define their professional identity and that they believe are right and appropriate." Thus solutions groups develop that reflect a sort of "bounded rationality" (March and Simon 1958), bounded not by familiar organizational routines but by familiar professional routines.

The two professions' different approaches can be seen in Edelman et al.'s (1992) study of wrongful discharge law. The personnel journals exaggerated the risk of wrongful discharge suits, blithely telling employers that bureaucracy-in the form of employment-at-will clauses-could protect them. Their authority came from the claim that they could predict the law's trajectory. "Since few employers actually read statute books or case reporters, . . . inter-organizational professionals have become social filters who determine how employers perceive legal threats, how they understand the law, and how they construct the compliance requirements" (Edelman 2002, p. 195). Legal journals more accurately represented the 


\section{Legal Compliance}

modest risk to employers and did not argue that a new, untested procedure could inoculate employers. Their authority came from the claim that they knew what the law actually said. Sutton and Dobbin (1996, p. 808) argue that personnel was the more entrepreneurial profession: "Their marginal position in firms inclines them to embrace unproven compliance recipes. The legal profession is, by nature, conservative and self-referential." Personnel managers were "explorers" of uncharted compliance measures, and employment lawyers were "settlers," working out details of these clauses after courts had found in favor of them.

Things might have evolved differently. It is easy to imagine a world in which civil rights issues would be monopolized by the field of law. France and Germany come close to that ideal, for personnel managers there have done little to respond to discrimination or harassment law (Bleich 2000; Saguy 2003). The role of personnel grew, historically, in the United States in large measure because in labor relations and civil rights law, legislation was ambiguous, and the common law system and fragmentation of authority across federal, state, and local governments made the law especially susceptible to change (Dobbin and Sutton 1998). Personnel claimed to be able to develop bureaucratic inoculations against future judicial and administrative rulings. It was not a foregone conclusion that personnel would play such a central role, whereas attorneys could count on disputes redounding to them and so were sure of playing a role.

Next we analyze the advice personnel experts and lawyers offered employers in print, developing predictions to be tested in the following section on the diffusion of harassment programs. Advice was directed at personnel experts within organizations and at lawyers who worked inside or consulted with organizations, and it provided arguments for these professionals to use as they attempted to sell executives on their solutions to the threat of sexual harassment liability. In 60 in-depth interviews with personnel managers in randomly sampled workplaces in California, Minnesota, New Jersey, and New York, conducted between 1997 and 2001, we learned that top managers approve training programs and grievance procedures. Many personnel managers complained of having to fight for programs. An HR (human resources) manager in publishing explained that a company executive killed the idea of harassment training, arguing, "If [sexual harassment] goes on, and if they attend training, they're going to realize: 'My God I was being harassed.' And they'll sue us." Professional journals provided the materials for professionals to counter such concerns.

Two Professions Proffer Advice on Harassment

The Civil Rights Act of 1964 did not outlaw sexual harassment by name but, after a rocky start in the courts, sexual harassment claims gained 
American Journal of Sociology

traction beginning in 1976. Three federal courts found that when a supervisor makes an employee's job contingent on submission to his sexual advances, he (or, rarely, she) has engaged in sex discrimination under Title VII of the act. In 1986, the Supreme Court found hostile-environment sexual harassment to be illegal, and in 1991, Congress added full compensatory and punitive damages to the plaintiff's pot. These three legal milestones brought new attention to harassment. Next we discuss each legal landmark and the advice that personnel and legal experts put forward.

Legal Landmark 1: Harassment Is Discrimination

Federal judges first heard the claim that on-the-job harassment constitutes sex discrimination nearly a decade after Congress passed the Civil Rights Act. At first they scoffed at the idea. In Barnes v. Train (13 FEP [D. D.C. 1974]), Corne v. Bausch and Lomb (390 F. Supp. 161 [D. Ariz. 1975]), and Tomkins v. Public Service Electric and Gas (422 F. Supp. 553 [D. N.J. 1976]) federal judges found that the Civil Rights Act does not cover sexual harassment. In the 1975 case the court found the actions of the supervisor charged with making employment contingent on sexual submission "to be nothing more than a personal proclivity, peculiarity, or mannerism. By his alleged sexual advances, Mr. Price was satisfying a personal urge" and concluded that "there is nothing in the (Civil Rights) Act which could reasonably be constructed to have it apply to verbal and physical sexual advances by another employee" (390 F. Supp at 163). In the 1976 case the District Court of New Jersey found that sexual assaults do not constitute sex discrimination because Title VII of the Civil Rights Act "is not intended to provide a federal tort remedy for what amounts to physical attacks motivated by sexual desire on the part of a supervisor and which happens to occur in a corporate corridor rather than a back alley" (422 F. Supp. 553).

The courts took employers by surprise in 1976 and 1977, defining harassment as employment discrimination. In 1976, in Williams v. Saxbe (413 F. Supp. 654), a federal court first found that when a supervisor fires a worker for refusing his sexual advances, he has discriminated under Title VII. In 1977 three federal courts ruled that it was illegal to make an employee, in Catharine MacKinnon's (1979) words, "put out or get out." These decisions made clear that employers were potentially liable for quid pro quo harassment, but they did not offer employers a way to protect themselves against liability. The decision overturning the 1974 ruling against Barnes implied that a written policy forbidding harassment might help to shield employers, but none of the rulings promoted internal grievance systems. 
Personnel's Advice

In writing about harassment, personnel experts exaggerated the risk of lawsuits by citing four surveys showing that between $70 \%$ and $90 \%$ of working women had experienced harassment. In 1976 the women's magazine Redbook published a mail-in questionnaire and reported that an astounding $90 \%$ of women had experienced unwanted sexual attention on the job (Safran 1976). The Redbook study and results of a survey conducted at a sexual harassment conference, showing that $70 \%$ of working women had been harassed, were widely reported in places like Personnel Journal (Hoyman and Robinson 1980) and the New York Times (Haberman 1980). When random-sample studies showed harassment to be less common, personnel writers rarely covered the news (Gallup Organization 1991; Spann 1990).

The grievance procedure.-Personnel professionals had established grievance procedures in union negotiations after the passage of the Wagner Act of 1935. They later sold these to nonunion firms as insurance against union drives so that by $1955,99 \%$ of unionized firms and $80 \%$ of large nonunion firms had grievance procedures (Selznick 1969). Later they formed civil rights grievance procedures in the same mold. After Department of Justice personnel experts created a civil rights procedure for internal complaints (Order No. 420-69, 34 FR 12281, July 25, 1969), experts recommended the same for high-profile signatories of Equal Employment Opportunity Commission (EEOC) consent decrees-AT\&T, the Bank of California, Pacific Gas and Electric, El Paso Natural Gas, and the major steel and trucking firms (Schaeffer 1975). By the late 1970s, personnel journals contended that grievance procedures could protect employers from Civil Rights complaints in court (Berenbeim 1980; Gery 1977, p. 203; Marino 1980, p. 32), despite the fact that grievance procedures had not yet protected a single employer in court (Edelman, Uggen, and Erlanger 1999).

Building on this history, personnel experts advised in articles in leading journals-Personnel, Public Personnel Management, the Harvard Business Review-that managers should establish a "good faith effort" to stop harassment by creating a special harassment grievance system (Spann 1990). Several articles discussed the harassment grievance procedure and training video that Adrienne Tomkins and her attorney had won in their out-of-court settlement in 1977 against Public Service Electric and Gas, after a district court overturned the 1976 dismissal of her case (Shah and Agrest 1979). The effect of these articles was to give personnel directors ammunition to take to their bosses. Similarly, MIT's ombudsperson Mary Rowe (1981, p. 46) argued in Harvard Business Review that a grievance procedure could intercept complaints en route to court. This was a com- 
American Journal of Sociology

mon claim, though Edelman et al. (1999) later found that grievance procedures do not reduce harassment complaints to the government. Others argued that a procedure could reduce harassment itself: "To be effective in lessening sexual harassment, [a specific harassment] procedure would have to be well-known throughout the organization, ensure confidentiality, and be under the authority of a highly credible, powerful individual" (Somers and Clementson-Mohr 1979, p. 26).

The most dramatic claim was that grievance procedures could protect employers in court. The EEOC issued "Guidelines on Discrimination Because of Sex" on November 10, 1980, that defined sexual harassment as sex discrimination under Title VII and advised "developing appropriate sanctions." Personnel managers translated this into a federal directive to set up grievance procedures and suggested that grievance procedures would provide legal protection (Hoyman and Robinson 1980). Two human resources professors published an article in Personnel in 1981 titled "Sexual Harassment: The Employer's Legal Obligations" that began: "Employers can protect themselves against liability for sexual harassment charges with a strong policy against such activity and a grievance procedure that expedites the processing of such complaints" (Linenberger and Keaveny 1981a, p. 60). They claimed that the courts had accepted grievance procedures: "Several courts have suggested steps an employer can take to escape liability. . . . Liability can be avoided if two conditions have been met: (1) The employer has a policy discouraging sexual harassment, and the employee failed to use an existing grievance procedure and (2) the sexually harassing situations are rectified as soon as the employer becomes aware of them" (Linenberger and Keaveny 1981a, pp. 6566). Linenberger and Keaveny (1981b, pp. 14-15) argued in the same year, in Human Resource Management (HRM), that "liability may be avoided if the ... employee has failed to present the matter to a publicized

\footnotetext{
${ }^{2}$ The guidelines defined harassment as: "Unwelcome sexual advances, requests for sexual favors, and other verbal or physical conduct of a sexual nature constitute sexual harassment when (1) submission to such conduct is made either explicitly or implicitly a term or condition of an individual's employment, (2) submission to or rejection of such conduct by an individual is used as the basis for employment decisions affecting such individual, or (3) such conduct has the purpose or effect of unreasonably interfering with an individual's work performance or creating an intimidating, hostile, or offensive working environment." It went on to suggest that harassment could be perpetrated by co-workers or others in the workplace, and then offered broad suggestions for preventing harassment: "Prevention is the best tool for the elimination of sexual harassment. An employer should take all steps necessary to prevent sexual harassment from occurring, such as affirmatively raising the subject, expressing strong disapproval, developing appropriate sanctions, informing employees of their right to raise and how to raise the issue of harassment under title VII, and developing methods to sensitize all concerned" (45 FR 74677, Nov. 10, 1980).
} 


\section{Legal Compliance}

grievance board" and went on to say that "to ensure compliance with Title VII" employers "must establish a written grievance procedure which explains the steps a victim of sexual harassment should follow to make her complaint known to upper management."

These articles fabricated judicial support for grievance procedures. In the Personnel article the authors did not actually cite a case, but in $H R M$ they cited Miller v. Bank of America (418 F. Supp. 233 N.D. Cal. 1976), in which the employer's claim that a grievance procedure should protect him had been rejected by the appellate court in 1979, as we will see below in the Harvard Law Review treatment of the same case. Defense attorneys trotted out grievance procedures as evidence that their clients did not condone harassment, to be sure, but the federal courts were generally unimpressed with this defense.

Even articles that accurately depicted case law tended to leave the impression that grievance procedures were mandatory. A January 1980 article in Personnel Administrator used a version of "Simon says," listing requirements the courts had established, such as rapid response to complaints, and then continuing: "It is extremely important for a company to have an established grievance procedure. . . . These procedures should be in written form and available to all employees" (Sawyer and Whatley 1980, p. 37). Only the closest reading would reveal that the courts had not mandated grievance procedures.

It was easy to argue that grievance procedures would provide legal protection; they were lawlike, with rights to counsel, to privacy, to an open hearing, to a neutral grievance panel, and to appeal. Sanctions were clearly defined. Personnel experts suggested that employees would have to use company procedures before appealing to the courts because that is how union grievance procedures worked for violations of labor law. But in civil rights cases complainants were not legally bound to exhaust company grievance systems before going to court. This would change, but not for 20 years and only for employees who agreed in writing to arbitrate employment disputes. In 2001, in Circuit City Stores v. St. Clair Adams (121 S. Ct. 1302), the Supreme Court decided by five to four that an employer could require a worker who had signed such an agreement to submit harassment claims to arbitration.

Harassment sensitivity training.-Personnel had long-run skill and management training and in the late 1960s developed "sensitivity" training for managers (Barley and Kunda 1992; Bennis 1963; Lawrence and Lorsch 1967; Lowin, Hrapchak, and Kavanaugh 1969; Robin 1967; Scott 1968). In the early 1970s personnel consultants began to recommend civil rights sensitivity training as a way to prevent discrimination, and this became widely popular under the moniker "diversity training" (Kelly and Dobbin 1998). 
American Journal of Sociology

From the time of the 1977 district court rulings, advocacy groups and HR experts recommended harassment training modeled on civil rights training. The Working Women's Institute told Business Week in 1979 (Business Week 1979, p. 120) that there was widespread interest in the in-house workshops they were then developing. In January of 1980 Sawyer and Whatley (1980, p. 38) wrote in Personnel Administrator that supervisors should be trained to understand the kinds of actions that might imperil employers: "Any action which makes current or future employment contingent on acquiescence to sexual advances or demands is illegal."

After the EEOC suggested in its 1980 guidelines that employers should make their policies against harassment known to employees, HR specialists began using language suggesting that the law required training. An article in Personnel Journal in 1981 titled "Effective Training and the Elimination of Sexual Harassment" begins with the bold (and groundless) claim: "Prominent communication of corporate policy opposing harassment in the workplace [i.e., training], and the existence of in-house complaint procedures, are mandatory since a number of judicial actions have placed strong reliance on such measures" (emphasis added; Kronenberger and Bourke 1981, p. 879; see also McIntyre and Renick 1982, p. 289; Renick 1980, p. 661). In contrast to these claims in the professional journals, our review of the case law revealed almost no discussion of training in the early 1980s. The notable exception was a district court case (Arnold v. Seminole 614 F. Supp. 853, 1985) in which a city government was required to institute training after the court decided it was responsible for ongoing and severe harassment of a female worker. In the court decision, training is discussed only as a remedy, not as a preventative measure to reduce employer liability.

Advice from Lawyers

Legal journals followed case law more closely and were more circumspect in offering concrete suggestions. Writers advised employers to consult with lawyers about individual cases and also raised concerns about the potential for grievance procedures to create more problems than they solved.

Call your attorney.-Lawyers argued that employers should take quick corrective action, in consultation with an attorney and in response to the specific facts of the case. The early law articles quoted the Tomkins district court case from 1977; Title VII is violated when a supervisor harasses "and the employer does not take prompt and remedial action after acquiring . . . knowledge" (e.g., Burge 1984, p. 802). This meant calling the lawyers in, disciplining the harasser, and ensuring that the harassed employee did not suffer retaliation for complaining. As John Attanasio (1982, p. 32) argued, the Constitution and Title VII "relieve an employer of 


\section{Legal Compliance}

liability . . . if it takes corrective action. In constitutional terms, the principle that a plaintiff cannot continue to litigate once she has been afforded her requested relief is commonly called "mootness." In the words of the Tomkins court, corrective action "in the face of litigation" is "equivocal in purpose, motive, and permanence" (quoted in Attanasio 1982, p. 35). Employers should seek counsel and offer a remedy the moment they get wind of harassment because courts did not give employers credit for changes made once a lawsuit was under way.

The legal advice to call your attorney was also based on a close reading of case law. Those who knew the details of sexual harassment cases at this time knew that the law was unsettled. Judges were experimenting with different legal theories and different standards for making a case. Their decisions made much of distinctions between types of harassment (quid pro quo and hostile environment) and type of harasser (supervisor and co-worker). Lawyers noted these distinctions and advised employers to call in an attorney to determine the best response to each individual case. By contrast, personnel advised the routinization of organizational response.

Grievance procedures: What you don't know can't hurt you.-Law reviews at first discounted the idea that the courts would favor grievance procedures, for in early quid pro quo cases, courts explicitly ruled that employers were "strictly liable" for harassment by supervisors-meaning that no bureaucratic precautions could reduce liability. As a Harvard Law Review (1984, p. 1461) piece noted, courts had not found that grievance procedures shielded employers: "The defendant in Miller was held strictly liable for harassment by all its employees, despite its express policy against sexual harassment and despite its creation of procedures for grievance resolution." The court in the Miller case cited four other federal appellate courts to argue that employers are strictly liable for harassment by supervisors, regardless of their policies and regardless of whether or not they were in the dark. The Review interpreted the EEOC's brief 1980 guidelines on sex discrimination as supporting grievance procedures, but argued: "Because the EEOC does not have the statutory authority to issue regulations . . . the Guidelines' standards can acquire the force of law only through adoption by the Supreme Court" (Burge 1984).

The courts had upheld different standards of liability in quid pro quo and hostile environment cases, but neither supported grievance procedures according to some law reviews. In quid pro quo cases, as in discrimination cases in which harassment was not an issue, the courts had upheld the strict liability standard: grievance procedures and other preventative measures did not absolve employers of liability for discrimination, and plaintiffs did not have to exhaust grievance mechanisms before going to court (Michigan Law Review 1978). In hostile environment cases, some lower 
American Journal of Sociology

courts had upheld a "knowledge" standard under which employers had to know of harassment to be held liable. Grievance procedures might thus be dangerous, giving employers knowledge that could put them at risk.

Law reviews could be quite blunt about the dangers of grievance procedures. The Harvard Law Review (1984, p. 1462) article reiterated that current case law discouraged grievance procedures, for employers had "an incentive to remain ignorant." Attanasio's (1982, p. 31, emphasis added) University of Cincinnati Law Review article warned, "Should courts continue to refuse to impute to unknowing employers the sexual discrimination of their supervisors, the policy against sexual discrimination could become see no evil, hear no evil. . . . The employer has little incentive to encourage [complaints] because the fact remains that lack of knowledge equals lack of liability." A 1984 North Carolina Law Review article dealt exclusively with the knowledge standard, pointing out that from the start, some courts had made employers liable for harassment only if they knew of it. The author quoted the Tomkins decision: "[We] conclude that Title VII is violated when a supervisor, with the actual or Constructive knowledge of the employer, makes sexual advances or demands toward a subordinate employee and conditions that employee's job status . . . on a favorable response" (Burge 1984, p. 803).

The standard of liability was a dominant theme in the legal articles published between 1980 and 1990. Journals for practicing lawyers told much the same story as academic law reviews. Ralph Baxter (1982, p. 20), writing in the American Bar Association journal Legal Economics, asked the question: "Is the employer liable for sexual harassment by its supervisors if it does not have "notice' of the conduct?" The answer was not clear. While some courts held employers liable for conduct they did not know of, "Other courts . . . have rejected this 'strict liability' standard" (Baxter 1982, p. 20). They have "held that an employer is not liable for sexual harassment by its supervisory employees unless it has notice of the conduct" (Baxter 1982, p. 20). In other words, ignorance is legal bliss.

After reviewing the professional advice on grievance procedures-and finding such divergence across the two professions-we reviewed the case law to try to understand what the courts were saying about these programs. We read the 23 district court decisions in hostile environment cases published in Lexis between 1977 (when federal courts found harassment to be illegal) and 1985 (the year before Meritor). While there was considerable variation across district courts in terms of the knowledge standard, it was clear that the courts favored prompt action when employers learned of harassment. The courts gave credit for prompt action, whether or not the employer had a formal grievance system in place.

Key to our argument is that the legal profession's claim to jurisdiction 


\section{Legal Compliance}

over matters of law was based in its knowledge of case law, and that the profession's modus operandi was to present relevant case law-in all its complexity - and not to speculate wildly about the future. The reigning advice from attorneys was to wait to see if the courts vetted grievance procedures and, in the meantime, to call in attorneys to customize a response to each complaint. Many lawyers were eventually won over to grievance procedures, but we expect that on the whole, executives who consulted attorneys on HR policy were less likely to install harassment procedures.

\section{Legal Landmark 2: The Supreme Court's 1986 Meritor Decision}

In its first harassment case, Meritor Savings Bank v. Vinson (40 FEP 1822, 477 U.S. 57 [1986]), the Supreme Court defined "hostile environment" harassment as illegal. Catharine MacKinnon (1979), who had put forward the idea, sat as co-counsel for Mechelle Vinson. Quid pro quo harassment was, to most minds, both clear-cut and rare. Hostile environment harassment, defined by MacKinnon as repeated, unwanted sexual attention, was neither clear-cut nor rare. Not only had the court recognized hostile environment harassment as illegal, but as the American Bar Association Journal noted in 1987, claims were growing: "Sexual harassment cases were on the rise even before [Meritor],' says William C. Bruce, a management labor lawyer in New Haven, Conn. 'The publicity surrounding [the case] accelerated the trend, as more potential plaintiffs saw that legal recourse is available" (Machlowitz and Machlowitz 1987, p. 80). Yet the court had not outlined how employers might protect themselves. In its opinion the court explicitly denied requests from counsel for both sides to clarify whether a grievance procedure could protect employers, and said that the "mere existence of a grievance procedure and a policy against discrimination" would not insulate employers from liability (106 S. Ct. at 2408-9). In saying that the "mere existence" of a procedure would not insulate employers, the court implied that a wellconstructed procedure might do so. Yet the court upheld the "knowledge" standard, which seemed to disfavor grievance procedures.

\section{Personnel's Advice after Meritor}

Personnel played up the court's indication that it might accept a grievance procedure as a defense, despite the court's refusal to accept Meritor's procedure. The profession also emphasized that the court had accepted a much broader definition of harassment that put many more employers at risk. Now they advocated "general" antiharassment grievance procedures to cover all bets (Bradshaw 1987; Domenick 1999, p. 786). An article 
American Journal of Sociology

in Public Personnel Management touted Madison, Wisconsin's 1981 policy which forbade "harassment on the basis of race, sex, religion, color, handicap, national origin, or sexual orientation" (Spann 1990, p. 59).

This was when training really took off. "Company confusion and concern have spurred a growth industry in training videos, seminars and consultants" reported U.S. News and World Report in 1986. "Chase Manhattan Bank discourages employees from touching each other and runs a 2-hour harassment-awareness program for managers. Atlantic Richfield distributes a film and training materials to corporate divisions, but the level of activity in each division varies. While the ambiguity surrounding sexual harassment perplexes many managers, it's a boon to the companies that market videotapes and training programs" (Brophy 1986, p. 56). Many of the 60 HR managers we interviewed between 1997 and 2001 parroted the press, describing the legal meaning of harassment as a moving target and emphasizing the need to train managers in what "hostile environment" harassment was. An HR manager at a high-technology company told us in 2000 that training was key: "There's lots of types of harassment. I think you have to start and make sure that the managers really understand what that is and make sure that they're not doing it and give them the skills to be able to spot that with their employees." Unclear about what sexual harassment really was, employers created prohibitions against behavior-a pat on the shoulder or romance between peers-that no court had found to constitute harassment, as legal scholar Vicki Schultz (2003) argues.

HR experts claimed that the training sessions they organized, modeled on the civil rights/diversity training programs they had advocated, would help to protect employers. Before the late 1990s, there was no evidence that the courts would limit legal liability for organizations with training. Even after the Supreme Court's 1998 ruling that training could help to shield employers against punitive damages in certain specific circumstances, HR experts overstated the legal support for training. As legal scholar Susan Bisom-Rapp (2001a, p. 156) argues: "Some training advocates represent [the Supreme Court decisions] as expressly mandating sexual harassment training, even though the decisions say absolutely nothing of the kind. Susan Meisinger, of the [Society for Human Resource Management], puts it this way: 'The Court said . . . if you don't provide some kind of sexual harassment training to your employees, you're going to be liable." That was far from the truth.

Lawyers after Meritor: Mixed Message from the Court

Law reviews and legal journals continued to advise employers to act quickly when an employee complained of harassment, consulting lawyers 


\section{Legal Compliance}

to determine an individualized remedy. As Gayle Ecabert wrote in the Cincinnati Law Review, "An employer who has been put on notice that sexual harassment exists in its workplace must take prompt remedial action or be held liable." But the issue of how employers could inoculate themselves in advance had not been decided in Meritor. The Meritor decision's "terse guidelines lack the adequate analysis and specific detail needed to make them of practical use" (Ecabert 1987, pp. 1195-96).

Reading the Meritor decision was tantamount to reading tea leaves. Employment lawyers favored training programs, and many now interpreted the Supreme Court guidelines to suggest that a well-crafted grievance procedure could protect employers. Yet both journals for practitioners and law reviews continued to caution that grievance procedures were not yet proven and might endanger employers. An article in Tort and Insurance Law Journal emphasized that in the Meritor case, the Supreme Court rejected "the bank's contention that the mere existence of a grievance procedure and Vinson's failure to use it should have absolved it" of responsibility and suggested that it was not yet clear whether any procedure could help to shield employers (Dolkart and Malchow 1987, p. 187). In 1990 the lead article in the Howard Law Journal reiterated the point that ignorance of hostile-environment harassment could protect employers: "an employer would not be held responsible for unlawful acts of supervisors that it neither knew of nor condoned" (Turner 1990, p. 10). In the Meritor decision the court had, after all, "rejected the bank's argument that it was insulated from liability by virtue of its policy against discrimination and a grievance procedure which Vinson failed to invoke" (Turner 1990, p. 15). Moreover, a grievance procedure could make harassment "foreseeable" for a repeat offender, heightening legal jeopardy. In Yates v. Avco Corp. (819 F.2d 630 [1987]) the sixth circuit court of appeals faulted Avco for having failed to prevent a "foreseeable" situation with an offender who had faced a formal grievance before. The Howard article emphasized that foreseeability would ratchet up the employer's legal liability: "the establishment of employer foreseeability resulting from the implementation of [a grievance procedure]—could have a significant impact in harassment cases" (Turner 1990, p. 17).

Law reviews reiterated that the courts had consistently upheld a "strict liability" standard for quid pro quo harassment and noted that for the increasingly common "hostile environment" cases, Meritor did not spell out what an effective procedure should look like. In Meritor the court introduced a negligence standard, under which grievance procedures and training programs might have been argued to constitute evidence that the employer was not negligent. Yet the law reviews tended to lead their stories with the court's refusal to vet the grievance procedure and to 
American Journal of Sociology

emphasize that employers could preclude a claim of negligence by responding to complaints rapidly.

Lower courts had not vetted grievance procedures either. Up to 1979, of the thousands of Title VII race and sex discrimination cases of all sorts, Edelman et al. (1999) found only four in which defendants claimed that grievance procedures should have shielded them from liability and none in which the courts accepted this defense. Between 1980 and the Meritor decision in 1986, they found only nine cases mentioning grievance procedures, and only four in which courts accepted the grievance procedure as even a partial defense. In four others, courts refused the idea that a grievance procedure could provide any protection. In the six years following Meritor, 36 defendants invoked grievance procedures, and in only 12 of those cases did the courts accept the procedure as even a partial defense. By the end of 1993, when our survey shows that over $60 \%$ of employers had harassment grievance procedures, there was scant evidence that they did much good.

Law review articles that mentioned training generally spoke favorably of it, but as we will see, they mentioned it rarely (Dolkart and Malchow 1987, p. 192; Ecabert 1987, p. 1191). A skeptical law professor later commented on the growing belief that training could solve the problem: "This belief, widely held and rarely questioned, has spawned a multi-billion dollar sexual harassment and diversity training industry staffed by consultants, management attorneys, and human resource professionals who offer programs aimed at litigation prevention" (Bisom-Rapp 2001b, p. 1).

\section{Legal Landmark 3: The Civil Rights Act of 1991}

Before 1991, sex discrimination cases could embarrass employers, but they rarely cost employers much because sex discrimination plaintiffs, unlike race discrimination plaintiffs, could not sue for compensatory and punitive damages. Successful harassment plaintiffs rarely netted more than a few months of lost wages. New civil rights legislation changed that. Now harassment plaintiffs could seek up to $\$ 300,000$ each against private sector employers, and the plaintiff's bar saw new potential in class action suits. John Motley, vice president of the National Federation of Independent Business, was quoted in Industry Week: "Let's face it, until now, virtually no business in the U.S. was exposed to jury trials, punitive damages, and compensatory damages in intentional-discrimination lawsuits except when dealing with racial harassment" (Verespej 1991, p. 64). 


\section{Legal Compliance}

Personnel Emphasizes New Risks and New Remedies

Personnel experts had always warned that harassment suits could be costly (Hoyman and Robinson 1980; Kronenberger and Bourke 1981), but their words were more convincing after the Civil Rights Act of 1991. In the 1980s, it was the threat of tort actions, not Title VII suits, that seemed to be the greatest financial risk to employers (Wymer 1983). For example, Los Angeles employment attorney Barbara Lindemann Schlei told the Wall Street Journal in 1985 (Jacobs 1985, p. 1): "[A] pinch at the water fountain has been the way of life in corporations. But that friendly pat or squeeze is this year's tort." In the wake of Meritor, the popular press reported that awards had increased. Awards had averaged $\$ 60,000$ to $\$ 70,000$, U.S. News (Brophy 1986, p. 8) reported, but CBS had recently agreed to settle a claim for $\$ 500,000$, and a U.S. district court awarded the former employee of an architectural firm $\$ 250,000$.

HR managers capitalized on the heightened attention to sexual harassment that followed Clarence Thomas's Supreme Court confirmation hearings, pointing out that the Civil Rights Act of 1991 increased the financial risk to private-sector employers. Business Week (1991, p. 190) warned industry before the act even passed that under current law, harassment victims could only win back pay and "reinstatement in a job they probably wouldn't want. The draft legislation would provide for damages of $\$ 50,000$ to $\$ 300,000$, depending on the size of the company." Industry Week wrote in "Longer Dockets, Deep Pockets" that "the increased legal liability business will face from the enactment of the Civil Rights Act of 1991 is sobering indeed" (Verespej 1991). In addition to publicizing huge jury awards-like the $\$ 7.1$ million that the largest law firm in the country, Baker and McKenzie, was initially ordered to paypersonnel journals also pointed out that class action suits could lead to multimillion dollar payouts (Bingham and Gansler 2002).

The private-sector HR managers we interviewed also told us that highprofile cases like that of Mitsubishi, which faced a 12-year class action that eventually netted $\$ 43.5$ million for harassment plaintiffs in 1998 , caught the attention of executives. A high technology manager told us in 2001: "It doesn't take too often to be pulled into the court by your earlobes and threatened with millions of dollars. ... It was the lawsuits that" pushed executives to adopt programs. In the same year a utility company manager told us he was updating harassment training "because we see and we read that that's been one of the fastest growing litigation areas. ... The courts are saying to protect yourself . . . you should have this, and this, and this in place." Cost also became more central in training. Another high-technology manager told us that during training, managers now "hear about some of the judgments awarded to people in sexual 
American Journal of Sociology

harassment cases, so they can see that it's something you're gonna have to pay for."

Personnel consultants stepped up their efforts to sell training programs and grievance procedures-focusing on the new risks for private sector employers in particular-and also retooled those grievance procedures in the wake of the Civil Rights Act of 1991. This legislation made sex discrimination and race discrimination cases more closely parallel by allowing punitive and compensatory damages for both kinds of claims. With the courts treating sex and race discrimination cases more similarly, it seemed sensible for employers to do so as well. Organizations already had blanket equal employment opportunity policies covering race and sex discrimination in place. Now personnel experts stepped up promotion of unified, "general antiharassment" procedures. We expect that general antiharassment programs would begin to spread in the period after the Civil Rights Act of 1991 and that private sector employers, who were most affected by this legal landmark, would be more likely to adopt new programs in this period.

\section{Lawyers' Mixed Message}

By the early 1990s, a growing number of employment lawyers had come to side with personnel experts, advising employers to establish grievance systems in the hope that those systems would reduce harassment. Now they argued less often that grievance procedures could backfire, but when they argued for grievance procedures it was to suggest that they might alter the climate, or at best make up part of a "good faith" effort defense. In assessing what employers could do to prevent harassment, Deborah Rhode (1992, p. 1465) wrote in the Southern California Law Review, "Internal employer grievance mechanisms should be strengthened to provide real sanctions, real damages, and real confidentiality protections." Lawyers did not make the extravagant claims that personnel experts made, that grievance mechanisms could inoculate employers in court. They continued to argue that swift response to news of harassment and a remedy that satisfies the complainant was the best way to stay out of court.

\section{Analysis of Personnel and Legal Journals}

We have been contrasting the advice offered in personnel and law journals. Next we document the pattern of advice we have been describing, graphically depicting what the personnel and legal journals were advising. We show that personnel journals recommended training as a remedy much more often than did law journals, and frequently recommended grievance 


\section{Legal Compliance}

procedures without mentioning that they might not protect employers. The average personnel article ran six pages and offered pithy positive advice. The average law journal article ran 29 pages and described the complexity of the legal situation. Many of these advised rapid response to harassment complaints but described the potential downside of grievance procedures.

To chronicle the published advice of personnel and legal experts, we collected all articles from the most cited, continuously published personnel and management journals, on the one hand, and law reviews and legal journals (for practitioners), on the other, between 1977 (when three federal district courts defined harassment as illegal) and 1997 (the year of our organizational survey on harassment programs). ${ }^{3}$ We combine personnel and management journals in one category because personnel experts wrote most of the management articles on harassment (a list of journals is available from the authors). We searched 41 personnel and management journals and 166 law journals (most law schools publish journals, replete with footnotes, hence there are more oft-cited law than personnel journals). We found 152 personnel and management articles and 281 law articles with "sexual harassment" in the title or abstract. We excluded letters to the editor and brief comments.

Personnel and management articles were more likely than legal articles to mention grievance procedures and harassment training, and markedly so given that legal articles were nearly five times as long as personnel articles.

What we find is that legal articles frequently mentioned the "strict liability" standard when they mentioned grievance procedures. In reading these articles, we discovered that they typically mentioned grievance procedures to make the point that the strict liability standard rendered such measures useless in court.

In figures 1 and 2 we show the number of articles on sexual harassment published in each three-year period in law and in personnel journals, and the number of those mentioning education and training (fig. 1) and strict liability and grievance (fig. 2). Because there were more law than personnel

\footnotetext{
${ }^{3}$ We chose the most cited law journals from Hein OnLine's "Core U.S./Most Cited Law Journals" list and the most cited personnel and business journals from the ISI Journal Citation Report, 2003 Social Sciences Edition. For personnel and business journals, we looked at the ISI categories business; business, finance; industrial relations and labor; management; psychology, applied; and public administration. We collected the articles from Hein OnLine, LegalTrac, LexisNexis, JStor, ABI/Inform, and EBSCO Academic/Master. Those not available electronically we photocopied and scanned. We ran scanned articles and nonsearchable pdf files through a character-recognition program to render them searchable. We read through the articles to eliminate those not primarily about sexual harassment. We used Google Desktop to search for terms. A full list of the journals is available from the authors upon request.
} 


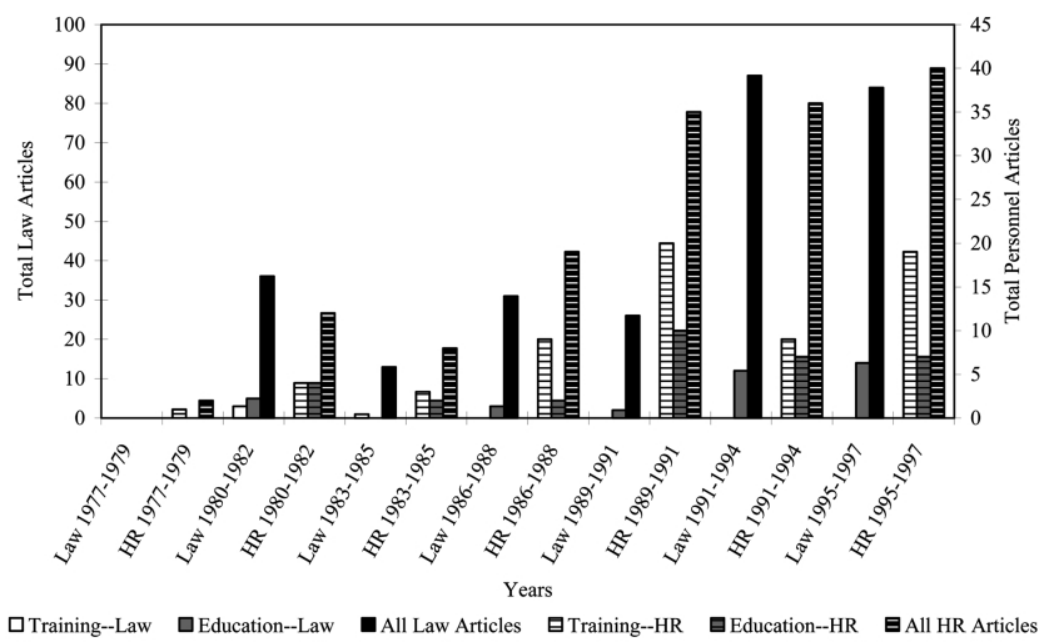

FIG. 1.-Law and HR articles on sexual harassment mentioning training and education

articles, we use two vertical axes (left axis for law, right for personnel). In figure 1, for instance, between 1980 and 1982 there were 36 law articles, five mentioning education and three mentioning training. In the same period, there were 12 personnel articles, four mentioning education and four mentioning training. Personnel articles were much more likely to mention education and training as part of their prescription. Overall, among the personnel articles, $43 \%$ mentioned training and $21 \%$ mentioned education. Among the law articles, $1 \%$ mentioned training and $13 \%$ mentioned education. This can be seen readily by scanning the solid light bars (law), and the striped light bars (HR). From the start, it was personnel experts who were advocating training and education as strategies for dealing with harassment.

Figure 2 shows that harassment articles in personnel journals frequently mentioned grievance procedures and rarely mentioned the "strict liability" standard, under which procedures provided no protection. We graph the number of HR/management articles mentioning "grievance" or "procedure." We also graph "strict liability." Compare the two professions. Fewer of the law articles mention grievance procedures. Overall, $26 \%$ of the law articles and $34 \%$ of the personnel articles mention grievance proceduresdespite the fact that the legal articles averaged nearly five times the length of the personnel articles. Moreover, in the critical period of the mid-1980s, when employers were choosing compliance strategies, law articles regularly discussed "strict liability" to argue that under this standard, preventative measures would not protect employers in court. Between 1983 


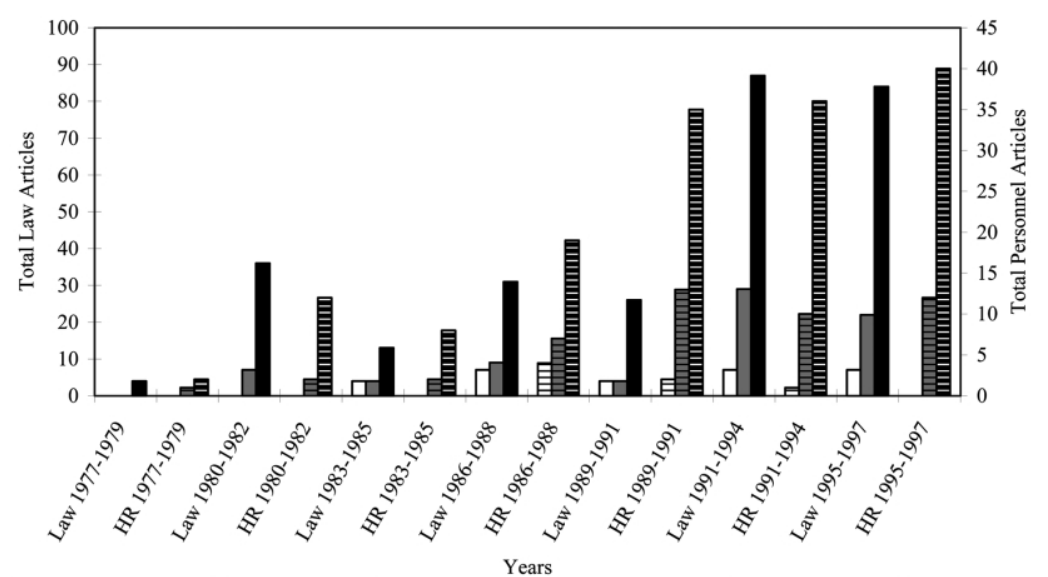

$\square$ Strict Liability--Law $\square$ Grievance--Law $\mathbf{\square}$ All Law Articles 日Strict Liability--HR 日 Grievance --HR $\mathbf{a}$ All HR Articles

FIG. 2.-Law and HR articles on sexual harassment mentioning strict liability and grievance.

and 1991, 17 law articles mentioned grievances, and 15 mentioned strict liability. Overall only seven of 155 personnel articles mentioned "strict liability."

We expect that employers consulting personnel experts will be significantly more likely to adopt both harassment procedures and training. We expect that employers consulting lawyers will be significantly less likely to adopt harassment procedures.

\section{Summary of Predictions}

Our review of the professional literature leads us to the following expectations. Personnel's tradition of creating bureaucratic remedies to problems of legal compliance gave it an advantage in appealing to executives interested in risk reduction. The legal profession's tradition of advising case-by-case remedies, and its resistance to routinizing solutions, put it at a disadvantage in appealing to the same executives. Each time a legal landmark seemed to heighten the risk of liability, we expect that executives became more likely to grab hold of personnel's two ready-made solutions. Executives who listened to lawyers were less likely to install grievance procedures; those who listened to personnel experts were more likely. The same should not hold for training, which personnel devised but which lawyers seldom objected to. Our historical account suggests the following hypotheses about organizational adoption of harassment programs:

Hypothesis 1.-Sexual harassment initiatives devised and promoted by personnel experts will spread more quickly after 1977, following the 
American Journal of Sociology

Barnes, Garber, and Tomkins decisions; again after 1986, following the Meritor decision; and again after 1991, following the new Civil Rights Act.

Hypothesis 2.-Employers with HR departments, those using HR consultants, and those with full-time antiharassment staff members will be more likely to adopt training and both kinds of harassment procedures.

Hypothesis 3.-Employers who relied on lawyers for advice were less likely to adopt grievance procedures.

Hypothesis 4.-Because the Civil Rights Act of 1991 allowed punitive damages in cases involving private-sector employers, private-sector organizations will be significantly more likely to install antiharassment programs after 1991.

\section{OTHER FACTORS SHAPING HARASSMENT PROGRAMS}

Here we review theories with predictions about antiharassment programs. We then outline the factors we control for in the analyses.

Organizational Demography and the Risk of Harassment

The contact hypothesis suggests that harassment increases with exposure to men (Gruber 1998; Gutek, Cohen, and Konrad 1990; KauppinenToropainen and Gruber 1993), and that the percentage of men in the workplace increases the incidence of harassment (De Coster, Estes, and Mueller 1999). If harassment itself elicits antiharassment measures, then the percentage of men should increase the use of sexual harassment procedures and training, and the percentage of nonminorities should increase the use of general harassment procedures that cover racial harassment.

Alternatively, when there are many women in an organization, managers may feel that the risk of a harassment claim is greater. Furthermore, in class action suits, a greater number of women does translate into a larger financial risk. If heightened sensitivity prompts antiharassment measures, then the percentage of women should increase the use of harassment procedures and training.

Size, Age, Inertia

Scale predicts the formalization of many policies (Blau and Schoenherr 1971; Kalleberg and Van Buren 1996). Bigger establishments, and those that are part of larger organizations, should be more likely to formalize harassment programs. Stinchcombe (1965) and Selznick (1957) both argue that as organizations age they become resistant to change, and less likely 


\section{Legal Compliance}

to adopt innovations. Because there were two waves of harassment grievance procedures-sexual and then general harassment procedures-we expect that inertia will stall employer replacement of sexual harassment policies by general harassment policies.

\section{Unionization}

Unions have historically called for codification of employee rights and due process procedures. Yet some union officials argued that their grievance procedure was the right venue for harassment claims, and this may have slowed adoption of distinct harassment procedures (Hauck 1999).

\section{Professionalization of the Workforce}

Neo-Marxist labor economists (Edwards 1979; Gordon, Edwards, and Reich 1982) contend that organizations in the primary labor market are most likely to protect the rights of employees. We expect that organizations in which the most common job is professional or managerial will be more likely to adopt antiharassment policies.

\section{DATA AND METHODS}

\section{Sample and Data Collection}

We drew a national sample of workplaces, stratified by sector and size, from the Dun and Bradstreet Market Identifier database, which Kalleberg et al. (1990, p. 664) describe as the most comprehensive of available sampling frames. The industries and sectors in the sample are diverse: food, chemicals, computer manufacturing, transportation manufacturing, trucking, wholesale trade, banking, business services, hospitals, nonprofit social services, and government. We set minimum size at 50 employees.

The Survey Research Center at the University of Maryland conducted telephone interviews in the latter half of 1997, completing 389 interviews that covered the history of HR practices back to 1965 . We wrote to HR managers, or general managers in organizations without HR managers, and asked permission to interview a person "familiar with the history of your human resource policies." Interviewers reported that they almost always spoke to HR managers in organizations with HR departments, and to general managers in the $30 \%$ of workplaces that lacked HR departments. Seventy-four percent of the organizations we were able to contact by phone cooperated. The overall response rate, which includes in the denominator those respondents we were not able to contact by telephone after repeated attempts, was $56 \%$. Similar surveys have yielded 
American Journal of Sociology

comparable response rates. Milliken, Martins, and Morgan (1998) report a rate of $18 \%$, Lincoln and Kalleberg (1985) report 35\%, Blau et al. (1976) report 36\%, Edelman (1992) reports 54\%, Dobbin et al. (1993) report 45\%, and Guthrie and Roth (1999) report 57\%. In 1997 the modal size was 430 employees; the mean was 1,445.

We investigated response bias with data from the 749 contacted establishments in the Dun and Bradstreet sampling frame. In logistic regression models of survey response, government agencies were significantly more likely to respond than nonprofits, service firms, or manufacturing firms. The factors that did not predict response were establishment size, organization size, subsidiary status, branch/headquarter status, region, and female chief executive. Response bias may affect the means for outcome variables, but we are confident that response bias does not contaminate the statistical results because we can control for the obvious sources of bias in the models.

For the discrete-time event-history analyses described below, we generated a data set with 9,844 organization-by-year spells of data. We retain organization-year records for each year in which the organization was at risk of adopting the practice in question. Organizations that had not adopted a practice by 1997 are included for the whole period. We omit a small number of organizational spells for which data for covariates are missing. The total number of spells considered in the analyses ranges from 5,911 for sexual harassment procedures to 7,414 for sexual harassment training programs. We model the adoption of 335 sexual harassment procedures, 249 general harassment procedures, and 284 antiharassment training programs.

Before the survey we conducted 19 face-to-face interviews with HR professionals in the New York metropolitan area, whom we selected randomly from Hoover's Directory of Human Resources Executives (1996). After the survey we conducted another 41 in-person interviews with HR executives in California, Minnesota, New Jersey, and New York, selected randomly from the Dun's list. In these interviews we investigated the decisions to adopt (or to avoid) a variety of HR policies and programs, including antiharassment programs. Above, we quote some of those managers.

\section{Measures and Model Specification}

Harassment policies.-We asked respondents whether, and when, they had established each harassment policy. We model the adoption of a sexual harassment procedure, a more elaborate general antiharassment procedure, and an antiharassment training program. In the survey, interviewers mentioned both kinds of harassment procedures and read definitions to 


\section{Legal Compliance}

respondents who did not recognize both. In figure 3 we show the percentage of employers with each practice, over time. Each practice rose dramatically over this period. Organizations that abandon a practice reenter the risk set, but this happened rarely.

Independent variables.-Table 1 lists univariate statistics. Measures were collected at the establishment level and vary over time, except where noted. Appendix table A1 reports a correlation matrix for all 9,844 spells of data. We asked about number employed at 10-year intervals, asked about years of large gains and losses, and interpolated size figures for intervening years. We asked about proportion minority and female at 10year intervals and interpolated. We measure the presence of union contract, HR department, sexual harassment staff position, HR consultants, and diversity training with binary variables. Our pilot interviews indicated that some HR departments consult attorneys about HR policyeither house counsel or outside counsel—and others do not, so we included a survey item to gauge that. The presence of a legal department did not have an effect in the models, hence we omit the variable for simplicity.

Multiestablishment firm, sector, and workforce professionalization are time invariant. For professionalization, we looked up the most common job in the Dictionary of Occupational Titles and assigned a score of 1 if it was defined as professional or managerial. We replaced missing values for the date of adoption of practices and structures with the median date. We did not estimate date of adoption for any dependent variable. In a sensitivity analysis we found that treating the estimated data as missing did not alter the results.

To examine the effects of legal landmarks we include overlapping binary variables for 1978-97 for the three district court findings, 1987-97 for the Supreme Court's Meritor decision, and 1992-97 for the Civil Rights Act of 1991. We begin each period in the first full year after the legal landmark. Overlapping periods make it easy to see whether each legal shift substantially increased the likelihood of adoption above and beyond the effects of previous policy shifts. We include a linear time trend to rule out the possibility that the periods capture a simple secular trend.

\section{Estimation}

We use discrete-time event-history methods because we do not know the exact timing of adoption within the spells and because we have many "tied" events, that is, years in which multiple employers adopt harassment policies (Allison 1995, pp. 220-22; Kalbfleisch and Prentice 1980). In par- 
American Journal of Sociology

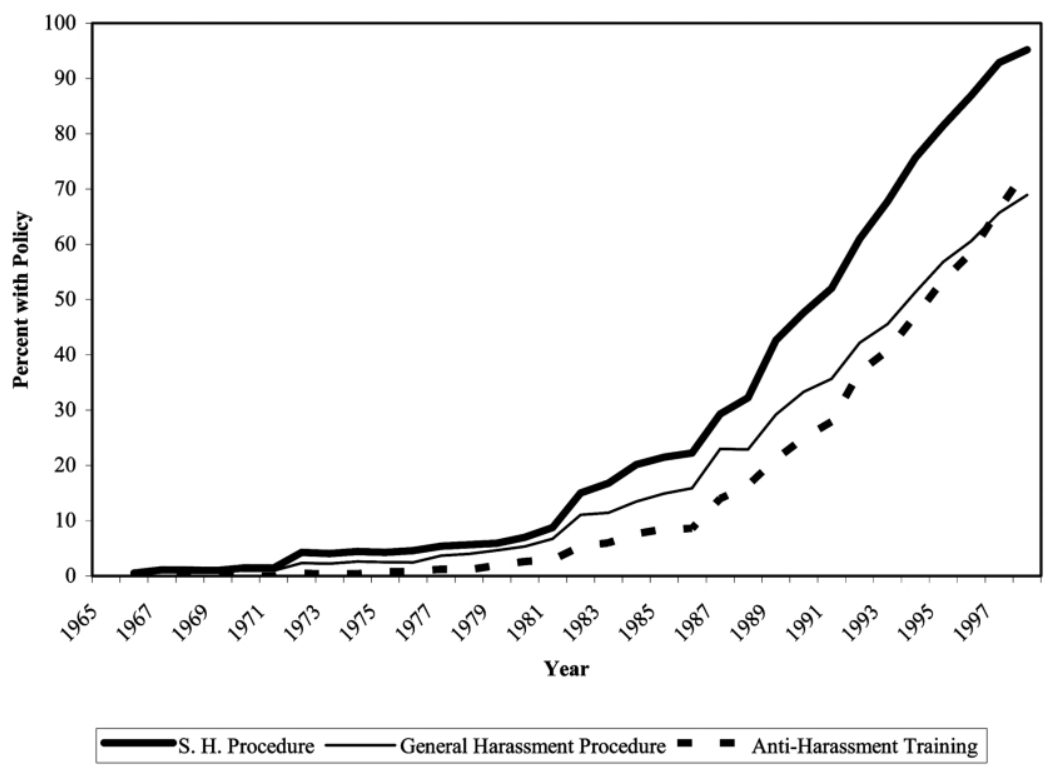

FIG. 3.-The spread of harassment policies

ticular, we employ discrete models where the hazard (instantaneous risk) at time $t$ for an organization with characteristics $i$ is:

$$
h\left(t \mid X_{i}\right)=h_{0}(t)^{\left(X_{i}^{\prime} \beta\right)} .
$$

Here $h_{0}(t)$ is a baseline hazard function describing the risk for organizations with baseline characteristics $X=0$, and the exponentiate $\left(X_{i}^{\prime} \beta\right)$ is a proportionate increase or reduction in risk associated with characteristics $X_{i}$.

Because the transformed data set contains annual spells, the hazard of adoption in each year is equivalent to $P_{i t}$, the conditional probability that the event occurs to organization $i$ in year $t$, given that it has not already occurred. We model the complementary log-log transformation of the cumulative survival function $\left(1-P_{i t}\right)$ on the covariates, specified for that time:

$$
\log \left[-\log \left(1-P_{i t}\right)\right]=\alpha(t)+\beta^{\prime} X_{i t} .
$$

The complementary log-log transformation takes a variable with the values of 0 and 1, marking the occurrence of the event in a given year, and changes it to a continuous value which ranges from minus infinity to plus infinity (Allison 1995, p. 216). The coefficients estimated by this procedure have a proportional hazards, or relative risk, interpretation. 
TABLE 1

VARIABLE DESCRIPTIONS

\begin{tabular}{|c|c|c|c|c|c|}
\hline Variable & Definition & Mean & $\mathrm{SD}$ & Min & Max \\
\hline \multicolumn{6}{|l|}{ Organizational factors: } \\
\hline Establishment size $\ldots \ldots \ldots \ldots \ldots \ldots \ldots$ & Log of number of employees & 5.76 & 1.57 & 0 & 11 \\
\hline Multiestablishment organization $\ldots \ldots \ldots$ & Part of a larger organization & .76 & .43 & 0 & 1 \\
\hline 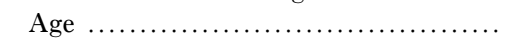 & Years since founding & 46.22 & 49.71 & 1 & 350 \\
\hline Union $\ldots \ldots \ldots \ldots \ldots \ldots \ldots \ldots \ldots \ldots \ldots \ldots \ldots \ldots \ldots \ldots \ldots \ldots \ldots$ & Presence of a union contract & .30 & .46 & 0 & 1 \\
\hline Professionalization $\ldots . \ldots \ldots \ldots \ldots \ldots \ldots$ & Core job is professional/managerial & .35 & .48 & 0 & 1 \\
\hline 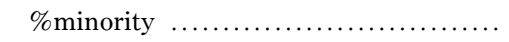 & Percentage of the workforce & 23.40 & 20.27 & 0 & 100 \\
\hline \%female $\ldots \ldots \ldots \ldots \ldots \ldots \ldots \ldots$ & Percentage of the workforce & 48.40 & 25.94 & 0 & 100 \\
\hline Public sector $\ldots \ldots \ldots \ldots \ldots \ldots \ldots \ldots \ldots \ldots \ldots \ldots$ & Local, state, or federal government & .28 & .45 & 0 & 1 \\
\hline Sexual harassment procedure...$\ldots \ldots \ldots$ & Presence of a procedure & .33 & .47 & 0 & 1 \\
\hline \multicolumn{6}{|l|}{ Professional influence: } \\
\hline HR department ...... & Presence of an HR department & .52 & .50 & 0 & 1 \\
\hline HR consultant . & Use outside HR consultants & .28 & .45 & 0 & 1 \\
\hline Legal consultant $\ldots \ldots \ldots \ldots \ldots \ldots \ldots \ldots$ & Consult with attorney on HR matters & .66 & .47 & 0 & 1 \\
\hline Sexual harassment staff position ....... & $\begin{array}{l}\text { Full-time employee working on sexual } \\
\text { harassment }\end{array}$ & .05 & .21 & 0 & 1 \\
\hline Diversity training employees $\ldots \ldots \ldots \ldots$ & Provide diversity training to employees & .11 & .32 & 0 & 1 \\
\hline \multicolumn{6}{|l|}{ Periods: } \\
\hline Time & Time trend (years since 1965) & 18.85 & 9.34 & 1 & 33 \\
\hline 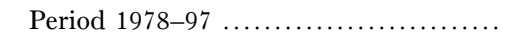 & Binary indicator & .69 & .46 & 0 & 1 \\
\hline Period $1987-97 \ldots \ldots \ldots \ldots \ldots \ldots \ldots \ldots \ldots \ldots$ & Binary indicator & .41 & .49 & 0 & 1 \\
\hline Period $1992-97 \ldots \ldots \ldots \ldots \ldots \ldots \ldots \ldots$ & Binary indicator & .23 & .42 & 0 & 1 \\
\hline \multicolumn{6}{|l|}{ Interactions: } \\
\hline Female $\times$ public sector $\ldots \ldots \ldots \ldots \ldots \ldots$ & Interaction & 12.16 & 22.48 & 0 & 100 \\
\hline Public $\times 1992-97 \quad \ldots \ldots \ldots \ldots \ldots \ldots \ldots$ & Interaction & .06 & .23 & 0 & 1 \\
\hline
\end{tabular}




\section{American Journal of Sociology}

We present three nested models for each outcome, identical except that we include sexual harassment procedure as an independent variable in models for the other two outcomes. We expect organizations that adopt this first-wave response will be slower to adopt the other two responses.

We explore whether variables representing our arguments show significant effects, net of those of variables representing existing theories. In the baseline models (table 2, models 1, 4, and 7) we include variables representing existing theories plus reliance on HR and legal professionals. In the subsequent models (table 2, models 2, 5, and 8) we add the three overlapping periods to see whether shifts in the legal environment have important effects. In models 3, 6, and 9, we consider sector differences. We add public $\times 1992-97$ to see whether private-sector organizations became more susceptible after personnel played up new punitive damages. We also include an interaction between sector and percentage female, because initial analyses revealed that feminization has different effects in public and private sectors.

\section{FINDINGS}

Personnel experts and lawyers mediate the effects of the law, and they do so in strikingly different ways. Each time a legal landmark appeared to raise organizational risk, more executives followed personnel's prescription of grievance procedures. Organizations that looked to HR professionals for advice were significantly more likely to adopt sexual harassment procedures and training. Organizations that looked to lawyers were less likely to adopt both sexual and general harassment procedures. Moreover, private firms alone became significantly more likely to adopt general harassment procedures after Congress approved punitive damage awards in private-sector cases.

\section{Legal Landmarks}

Executives embraced personnel's prescriptions-sexual and general harassment procedures-in greater numbers after both the 1977 district court rulings and the 1986 Meritor ruling. These effects can be seen in the significant coefficients for each time period, in models 2 and 5 . They also increased use of sexual harassment procedures after the Civil Rights Act of 1991, as can be seen in model 2. Each significant coefficient suggests that a legal landmark ramped up adoptions net of the linear increase captured by the time trend. Coefficients for the latter two periods reflect increases in the propensity to adopt above and beyond both the time trend and the earlier period effects, suggesting a stepwise rise. The legal land- 


\section{Legal Compliance}

marks do not show the same stepwise effects on training programs, although coefficients for time trend show an increasing risk.

The third legal landmark, the Civil Rights Act of 1991, changed harassment law only for private-sector firms by introducing the possibility of punitive damage awards for these organizations. If private firms are more susceptible to adopting harassment policies after 1991, period 199297 will show a positive effect, and public $\times 1992-97$ will show a negative effect. For the general harassment procedure, model 5 suggests that the Civil Rights Act of 1991 has no effect. In fact, sector differences have masked the act's effect. In model 6, the coefficient for period 1992-97 $(.502 ; P<.05)$, shows a positive effect in the private sector, and the coefficient for public $\times 1992-97(-.769 ; P<.05)$ shows that this effect is washed out in public agencies. Model 6 fits significantly better than the models without interactions. General harassment procedures-which institute parallel treatment of race and sex harassment claims-are the only practices that show these sector differences.

Professional Influence on Organizational Practices

We expected that HR departments, HR consultants, and full-time sexual harassment experts would encourage employers to adopt all three policies. For sexual harassment procedures, the presence of an HR department shows a strong and consistent effect in models 1 through 3 . In models 4 , 5 , and 6, none of the personnel measures affected general harassment procedures, but note two things. First, personnel's effects can be seen in the coefficients for legal landmarks, for personnel invented the harassment procedure, and only personnel unequivocally backed it. Second, in models 4,5 , and 6 , the first-wave response (sexual harassment procedure) shows a negative effect on general harassment procedure. Sexual harassment procedures were predicted by personnel variables, suggesting that executives who relied on HR experts were more likely to add sexual harassment procedures early, but then less likely, because of the inertia of those early procedures, to add general harassment procedures.

The effects of HR experts on the adoption of training are evident through three different variables. In models 7, 8, and 9, HR consultant, sexual harassment staff position, and diversity training all show significant positive effects. HR department does not show an effect here, but does show an effect when we omit HR consultant. The positive effect of diversity training suggests that where trainers have a toehold, they sell harassment training. Employers who consulted with attorneys were less likely to adopt sexual harassment procedures, in models 1,2 , and 3, and general harassment procedures, in models 4,5 , and 6 . They were no less likely to adopt harassment training, as predicted. 
TABLE 2

Estimates of the Adoption of Sexual Harassment Policies

\begin{tabular}{|c|c|c|c|c|c|c|c|c|c|}
\hline \multirow{2}{*}{ VARIABLE } & \multicolumn{3}{|c|}{$\begin{array}{c}\text { Sexual Harassment } \\
\text { Procedure }\end{array}$} & \multicolumn{3}{|c|}{$\begin{array}{c}\text { GENERAL HARASSMENT } \\
\text { PROCEDURE }\end{array}$} & \multicolumn{3}{|c|}{ ANTIHARASSMENT TRAINING } \\
\hline & 1 & 2 & 3 & 4 & 5 & 6 & 7 & 8 & 9 \\
\hline Multiestablishment organization & $\begin{array}{l}.189 \\
(.138)\end{array}$ & $\begin{array}{l}.196 \\
(.139)\end{array}$ & $\begin{array}{l}.193 \\
(.139)\end{array}$ & $\begin{array}{l}.483 * * \\
(.160)\end{array}$ & $\begin{array}{l}.493 * * \\
(.160)\end{array}$ & $\begin{array}{l}.497 * * \\
(.160)\end{array}$ & $\begin{array}{l}.276 \\
(.156)\end{array}$ & $\begin{array}{l}.285 \\
(.155)\end{array}$ & $\begin{array}{l}.259 \\
(.157)\end{array}$ \\
\hline Age & $\begin{aligned}-.002 \\
(.001)\end{aligned}$ & $\begin{aligned}-.002 \\
(.001)\end{aligned}$ & $\begin{aligned}-.002 \\
(.001)\end{aligned}$ & $\begin{array}{c}-.003 \\
(.002)\end{array}$ & $\begin{array}{c}-.003 \\
(.002)\end{array}$ & $\begin{array}{l}-.003 \\
(.002)\end{array}$ & $\begin{aligned}-.004 * \\
(.002)\end{aligned}$ & $\begin{array}{r}-.004 * \\
(.002)\end{array}$ & $\begin{array}{r}-.003^{*} \\
(.002)\end{array}$ \\
\hline Professionalization ...... & $\begin{array}{c}.013 \\
(.129)\end{array}$ & $\begin{array}{c}.007 \\
(.128)\end{array}$ & $\begin{array}{c}.014 \\
(.129)\end{array}$ & $\begin{array}{l}.389 * * \\
(.144)\end{array}$ & $\begin{array}{l}.383 * * \\
(.144)\end{array}$ & $\begin{array}{l}.391 * * \\
(.144)\end{array}$ & $\begin{array}{l}.274^{*} \\
(.139)\end{array}$ & $\begin{array}{c}.263 \\
(.139)\end{array}$ & $\begin{array}{l}.290^{*} \\
(.139)\end{array}$ \\
\hline$\%$ minority & $\begin{aligned}-.002 \\
(.003)\end{aligned}$ & $\begin{aligned}-.003 \\
(.003)\end{aligned}$ & $\begin{aligned}-.002 \\
(.003)\end{aligned}$ & $\begin{array}{l}.004 \\
(.003)\end{array}$ & $\begin{array}{l}.004 \\
(.003)\end{array}$ & $\begin{array}{l}.005 \\
(.003)\end{array}$ & $\begin{array}{c}-.004 \\
(.003)\end{array}$ & $\begin{aligned}-.004 \\
(.003)\end{aligned}$ & $\begin{array}{r}-.003 \\
(.003)\end{array}$ \\
\hline$\%$ female & $\begin{aligned}-.003 \\
(.002)\end{aligned}$ & $\begin{aligned}-.003 \\
(.002)\end{aligned}$ & $\begin{array}{r}-.004 \\
(.002)\end{array}$ & $\begin{array}{c}-.001 \\
(.003)\end{array}$ & $\begin{array}{c}-.001 \\
(.002)\end{array}$ & $\begin{array}{c}-.003 \\
(.003)\end{array}$ & $\begin{aligned}-.003 \\
(.003)\end{aligned}$ & $\begin{array}{r}-.003 \\
(.003)\end{array}$ & $\begin{array}{c}-.006^{*} \\
(.003)\end{array}$ \\
\hline HR department & $\begin{array}{l}.299 * \\
(.135)\end{array}$ & $\begin{array}{l}.304 * \\
(.136)\end{array}$ & $\begin{array}{l}.289^{*} \\
(.136)\end{array}$ & $\begin{array}{l}-.008 \\
(.155)\end{array}$ & $\begin{array}{l}-.028 \\
(.156)\end{array}$ & $\begin{array}{l}-.048 \\
(.156)\end{array}$ & $\begin{array}{l}.193 \\
(.147)\end{array}$ & $\begin{array}{c}.180 \\
(.147)\end{array}$ & $\begin{array}{c}.163 \\
(.147)\end{array}$ \\
\hline
\end{tabular}




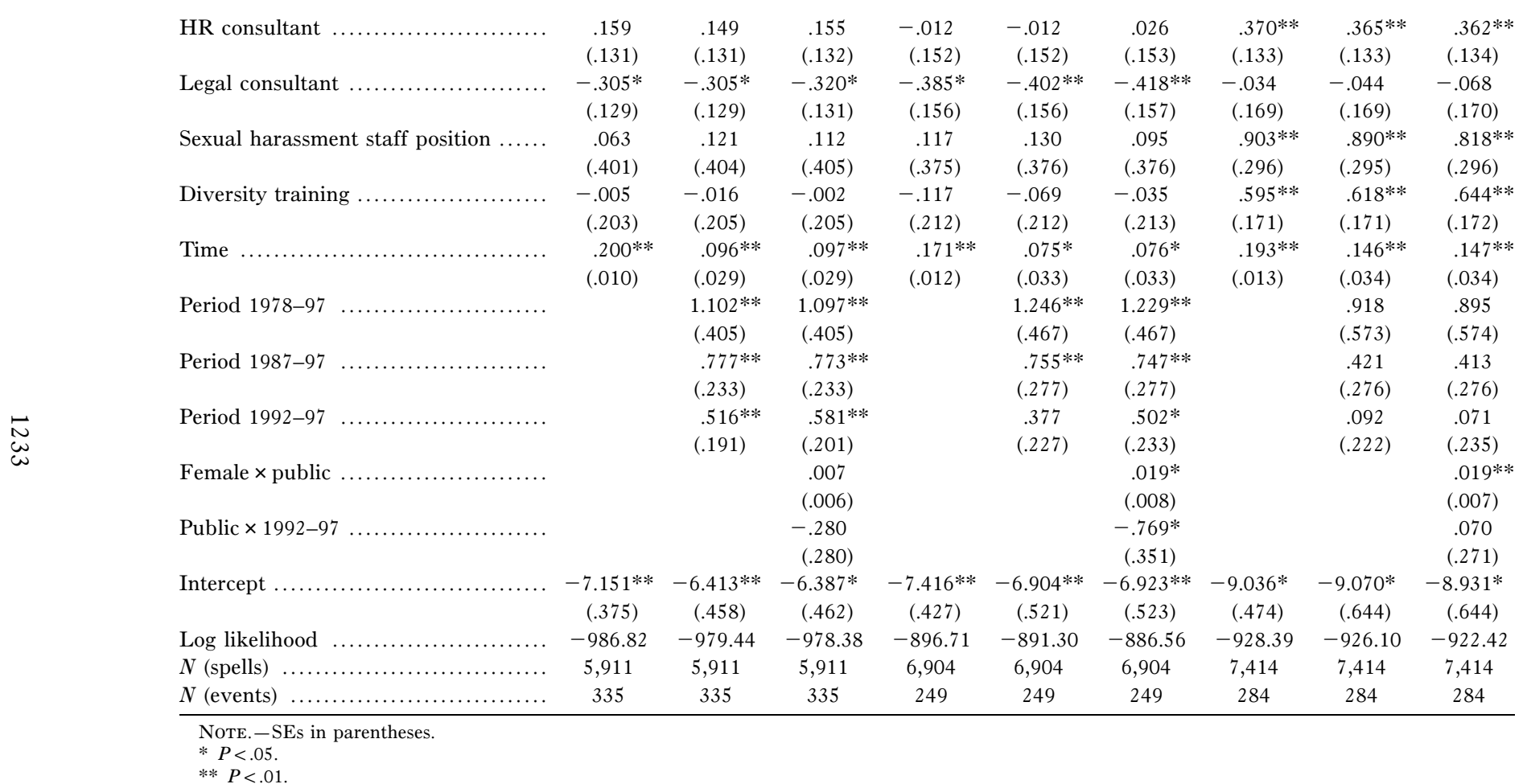


American Journal of Sociology

Other Factors

Control variables generally show the expected effects or no effects at all. Large employers are consistently more likely to adopt each kind of harassment policy. Multiestablishment organization has a positive effect on general harassment procedure. Age shows the expected negative effect on training program. Unionization does not show significant effects. Workforce professionalization shows positive effects on general harassment procedures and training.

Sex composition at first appears not to have an effect, contradicting both the contact hypothesis, that predominantly male organizations will produce more harassment and thus more programs to curb it, and the sensitivity hypothesis, that in predominantly female organizations, managers will be more sensitive to the issue. However, when we introduced an interaction in exploratory analysis, we discovered that feminization stimulates public agencies, but not private firms, to adopt general harassment procedures and antiharassment training. In model 6, percentage female taps feminization in the private sector and does not show a significant effect, but female $\times$ public shows a significant positive effect. The same pattern can be seen for training in model 9. For the public sector, an increase in feminization increases the hazard of adopting both measures. ${ }^{4}$

\section{CONCLUSION}

When three federal courts ruled in 1977 that harassment constituted sex discrimination, personnel experts played two old standards from their repertoire, the grievance procedure and the training program. These came to be ubiquitous. We show not merely that personnel experts got their way, but that they convinced executives to listen to their advice even as lawyers advised executives to deal with cases individually and swiftly, and even as some lawyers advised that grievance procedures might backfire. Personnel promised a bureaucratic vaccine against lawsuits for harassment. They built that promise on an analogy to the union grievance mechanism, for aggrieved unionists were contractually required to use arbitration. The promise appealed to executives concerned about legal liability. Attorneys' advice, to respond swiftly to complaints with an acceptable remedy overseen by a lawyer, was based in their tradition of case consultation and attention to precedent. This did not play so well to

\footnotetext{
${ }^{4}$ The sector difference is significant for general harassment procedures when feminization is in the range of $0 \%-43 \%$, and for training when feminization is in the range $0 \%-11 \%$.
} 


\section{Legal Compliance}

managers who wanted a routine inoculation against liability. Every time a legal landmark seemed to increase the risk of lawsuit, executives became more likely to take personnel's unproven advice. Executives who consulted HR experts were more likely to follow that advice. And those who consulted lawyers were more likely to take their advice and hold off on grievance procedures. In the end, the growing risk of liability and the absence of clear judicial guidance led almost all employers to embrace the preventative measures on offer, grievance procedures, and training.

Viewed from the perspective of Abbott's holistic approach to understanding the system of professions, Edelman et al.'s (1999) insight that in 1998 the Supreme Court vetted personnel's recommendations takes on new meaning. The case of harassment suggests that the courts follow organizational practice, to be sure-that the law is endogenous to organizations, in Edelman's (2002) famous phrasing-but also that executives are becoming increasingly important in adjudicating professional expertise, and that their preferences are becoming increasingly salient in professional turf battles. Their preferences are now more likely to be written into case law as well.

One consequence of the organizational absorption of vast domains of social activity over the last two centuries is that jurisdictional struggles among expert groups are increasingly played out within networks of organizations rather than within nation-states (Abbott 1988). Employer response to sexual harassment law highlights the changing character of these struggles. While the Supreme Court eventually endorsed personnel's compliance approach for cases with certain fact patterns, the profession's authority did not come through state licensure. Instead, executives gave personnel unofficial license to take charge of harassment by adopting grievance procedures and training programs in large numbers. America's common law system and regulatory uncertainty create an opening for expert groups to claim legal expertise in executive suites. Lawyers' claims to expertise in legal precedent may be less relevant than claims from other groups to substantive knowledge, and to remedies appropriate to large organizations (Dobbin and Sutton 1998; Zippel 2006). This goes for HR managers in the field of civil rights, but it also goes for engineers in environmental regulation and health and safety standards, for accountants in benefits regulation, and for both accountants and financial managers in securities regulation (Dobbin and Sutton 1998; Fligstein 1990; Ocasio and Kim 1999; Stryker 2000). If accountants and justices of the peace won certain corporate legal work early in England because of a scarcity of lawyers, as Abbott (1988) argues, other experts groups are winning legal work in American organizations as executives seek bureaucratic remedies to substantive regulatory problems, remedies of the sort lawyers seldom offer. Executives favor innovations that are smooth running and 
American Journal of Sociology

predictable, and so favor systems that routinize solutions and minimize discretion (Van de Ven et al. 1999). Lawyers tend to offer solutions that treat cases individually and that rely on the discretion of corporate counsel.

The increasing complexity of management domains subject to regulation-personnel administration, but also environmental protection, health and safety, benefits administration, and financial reporting-has contributed to the trend, we suspect, in two ways. On the one hand, it has catalyzed executive interest in routinized, smooth-running solutions to problems of reporting and regulatory compliance, because executives equate solving a complex problem with routinizing a solution. On the other hand, it has meant the increasing specialization of regulatory expertise. Corporations more and more retain specialist lawyers to handle taxes, employment, mergers, bankruptcy, and a host of other issues. Corporate law has not been a unified field for some time. They also increasingly turn to a host of other professional groups, with substantive rather than legal expertise, for compliance strategies.

Attorneys' superior grasp of the law would seem to give them the upper hand in professional turf battles, but the legal profession's ethos of caution and attention to precedent puts it at a distinct disadvantage when dealing with executives seeking to reduce risk in the context of legal uncertainty. Executives do not always seek the most efficient solutions to problems of management, as organizational sociologists and agency theorists have long argued (Fligstein 2001; Jensen and Meckling 1976; March and Simon 1958). In the case of harassment, they embraced remedies that had no more than a shot at reducing risk. Yet attorneys offered no distinct preventative-not even one that was a long shot-being reluctant to design a preventative that the courts might reject. In the case of sexual harassment, executives' penchant for stable bureaucratic solutions appears to have favored personnel's grievance procedures and training programs, even though there was no cost-benefit analysis that could support them. Attorneys' arguments that employers should simply respond promptly to complaints of harassment were no consolation to executives who wanted something to point to as evidence they had addressed the problem. Attorneys themselves came around by the mid-1990s, as more and more employment-law experts advised adopting grievance mechanisms to handle conflicts, but they remained reticent to argue that grievance mechanisms would actually protect employers in court. Lawyers may well have recognized that at a certain point in the diffusion process, the lack of a harassment grievance mechanism signaled recklessness. That appears to have been the Supreme Court's view, for the court resisted vetting grievance procedures in 1986, when they were still relatively rare, but accepted them in 1998, by which time they were commonplace.

Our analysis highlights the increasing importance of executives in de- 


\section{Legal Compliance}

fining professional expertise and jurisdiction, and the declining salience of judges and legislatures. It highlights the increasing importance of managerial risk as an incentive and, perhaps, the declining importance of problem remediation. The popular programs were oriented to reducing the risk of lawsuit more than to reducing the incidence of harassment. Eventually they were shown to reduce legal risk, because the courts accepted as legal what had become popular, but not to reduce the incidence of harassment. Executives spent untold millions setting up training programs that have not yet been shown to reduce harassment (Bisom-Rapp 2001a) and establishing grievance procedures that were unproven in court and that did not reduce complaints to the government (Edelman et al. 1999). We have been arguing that executives prefer formal bureaucratic remedies that can routinize legal compliance, but it is also the case that the courts have come to reinforce such solutions because they constitute standards that can be applied across cases. What matters, before the courts, is not whether the employer has a system for addressing harassment complaints and preventing harassment that has been proven effective, in the workplace in question or anywhere for that matter, but whether the employer has a system that symbolizes commitment to those ideals (Sturm 2001, p. 563). Thus executives and judges alike have contributed to personnel's success, for personnel had a plausible compliance remedy that offered executives a formalized solution, and judges a bright-line standard by which they could assess employers. Neither group seemed particularly concerned that the solution was, perhaps, of no more than ceremonial value (Meyer and Rowan 1977). 
APPENDIX A

TABLE A1

Correlation Matrix

\begin{tabular}{|c|c|c|c|c|c|c|c|c|c|c|c|c|c|c|c|c|c|c|c|c|c|c|}
\hline & 1 & 2 & 3 & 4 & 5 & 6 & 7 & 8 & 9 & 10 & 11 & 12 & 13 & 14 & 15 & 16 & 17 & 18 & 19 & 20 & 21 & 22 \\
\hline \multicolumn{23}{|l|}{ 1. Establishment size } \\
\hline $\begin{array}{l}\text { 2. Multiestablishment } \\
\text { organization }\end{array}$ & .13 & & & & & & & & & & & & & & & & & & & & & \\
\hline 3. Age & .20 & .03 & & & & & & & & & & & & & & & & & & & & \\
\hline 4. Union & .31 & .14 & .23 & & & & & & & & & & & & & & & & & & & \\
\hline 5. Professionalization & .06 & -.21 & -.05 & -.22 & & & & & & & & & & & & & & & & & & \\
\hline 6. HR department & .43 & .09 & .01 & .13 & .06 & & & & & & & & & & & & & & & & & \\
\hline 7. HR consultant & .29 & .08 & .11 & .11 & .05 & .34 & & & & & & & & & & & & & & & & \\
\hline 8. Legal consultant & .31 & .09 & .05 & .18 & -.02 & .41 & .36 & & & & & & & & & & & & & & & \\
\hline \multicolumn{23}{|l|}{ 9. Sexual harassment staff } \\
\hline position & .09 & .07 & -.01 & .02 & .02 & .11 & .14 & .12 & & & & & & & & & & & & & & \\
\hline 10. Diversity training & .21 & .04 & .03 & .08 & .06 & .23 & .28 & .21 & .20 & & & & & & & & & & & & & \\
\hline 11. \%nonwhite & .03 & -.01 & -.07 & -.07 & -.03 & .05 & .05 & .06 & .06 & .07 & & & & & & & & & & & & \\
\hline 12. \% female & -.02 & -.19 & -.05 & -.12 & .31 & -.06 & .02 & -.03 & -.01 & .06 & .00 & & & & & & & & & & & \\
\hline 13. Public sector & .08 & .30 & .28 & .31 & -.27 & -.11 & .05 & .03 & -.01 & .00 & -.10 & -.10 & & & & & & & & & & \\
\hline 14. Time & .11 & .00 & .01 & .10 & .02 & .24 & .37 & .42 & .19 & .37 & .14 & .11 & -.06 & & & & & & & & & \\
\hline 15. Period 1978-97 & .08 & -.01 & .01 & .10 & .01 & .20 & .27 & .34 & .13 & .23 & .11 & .10 & -.05 & .83 & & & & & & & & \\
\hline 16. Period $1987-97$ & .10 & .01 & .01 & .07 & .02 & .21 & .34 & .38 & .18 & .35 & .12 & .09 & -.05 & .83 & .56 & & & & & & & \\
\hline 17. Period 1992-97 & .10 & .01 & .02 & .04 & .02 & .17 & .31 & .29 & .17 & .39 & .10 & .07 & -.04 & .69 & .37 & .66 & & & & & & \\
\hline 18. Female $\times$ public sector & .08 & .26 & .18 & .29 & -.20 & -.07 & .07 & .04 & .01 & .02 & -.10 & .11 & .88 & .01 & .01 & .00 & .00 & & & & & \\
\hline 19. Public $\times 1992-97$ & .09 & .12 & .14 & .18 & -.09 & .05 & .18 & .13 & .09 & .23 & -.01 & .01 & .40 & .31 & .17 & .29 & .44 & .41 & & & & \\
\hline \multicolumn{23}{|l|}{ 20. Sexual harassment } \\
\hline procedure & .17 & .03 & -.02 & .08 & .06 & .32 & .35 & .36 & .26 & .39 & .06 & .08 & -.08 & .66 & .46 & .64 & .61 & -.01 & .26 & & & \\
\hline 21. Harassment training & .25 & .07 & .00 & .08 & .06 & .31 & .39 & .32 & .33 & .52 & .07 & .05 & -.02 & .54 & .35 & .53 & .55 & .04 & .28 & .66 & & \\
\hline 22. General procedure & .13 & .05 & -.05 & .00 & .00 & .23 & .28 & .27 & .26 & .28 & .13 & .06 & -.12 & .52 & .36 & .50 & .47 & $\begin{array}{r}-.04 \\
-.06\end{array}$ & .14 & .66 & .54 & \\
\hline
\end{tabular}




\section{Legal Compliance}

\section{REFERENCES}

Abbott, Andrew D. 1988. The System of Professions: Essays on the Division of Expert Labor. Chicago: University of Chicago Press.

Allison, Paul D. 1995. Survival Analysis Using the SAS System. Cary, N.C.: SAS Institute.

Attanasio, John B. 1982. "Equal Justice under Chaos: The Developing Law of Sexual Harassment." University of Cincinnati Law Review 51:1-41.

Barley, Stephen R., and Gideon Kunda. 1992."Design and Devotion: Surges of Rational and Normative Ideologies of Control in Managerial Discourse." Administrative Science Quarterly 37:363-400.

Baxter, Ralph H., Jr. 1982. "Sexual Harassment Claims: The Issues." Legal Economics 8:15-25.

Bennis, Warren G. 1963. "A New Role for the Behavioral Sciences: Effecting Organizational Change." Administrative Science Quarterly 8:125-65.

Berenbeim, Ronald. 1980. Non-union Complaint Procedures. New York: Conference Board.

Bingham, Clara, and Laura Leedy Gansler. 2002. Class Action: The Story of Lois Jenson and the Landmark Case That Changed Sexual Harassment Law. New York: Doubleday.

Bisom-Rapp, Susan. 2001a. "Fixing Watches with Sledgehammers: The Questionable Embrace of Employee Sexual Harassment Training by the Legal Profession." University of Arkansas at Little Rock Law Review 24:147-68.

- 2001b. "An Ounce of Prevention Is a Poor Substitute for a Pound of Cure: Confronting the Developing Jurisprudence of Education and Prevention in Employment Discrimination Law." Berkeley Journal of Employment and Labor Law 22:1-46.

Blau, Peter M., Cecilia McHugh Falbe, William McKinley, and Phelps K. Tracy. 1976. "Technology and Organization in Manufacturing." Administrative Science Quarterly 21:20-40.

Blau, Peter M., and Richard A. Schoenherr. 1971. The Structure of Organizations. New York: Basic.

Bleich, Erik. 2000. "Antiracism without Races: Politics and Policy in a 'Color-Blind' State." French Politics and Society 18:48-74.

Bradshaw, David. 1987. "Sexual Harassment: Confronting the Troublesome Issues." Personnel Administrator 32:50-52.

Brandes, Stuart D. 1976. American Welfare Capitalism, 1880-1940. Chicago: University of Chicago Press.

Brody, David. 1980. Workers in Industrial America. New York: Oxford University Press.

Brophy, Beth. 1986. "Sexual Harassment: Crossing the Line into Verboten Territory." U.S. News and World Report, December 8.

Burge, David J. 1984. "Employment Discrimination—Defining an Employer's Liability under Title VII for On-the-Job Sexual Harassment: Adoption of a Bifurcated Standard." North Carolina Law Review 62:795-803.

Business Week. 1979. "Sexual Harassment Lands Companies in Court." October 1.

_. 1991. "Two Breakthroughs for Civil Rights." November 11.

De Coster, Stacy, Sarah Beth Estes, and Charles W. Mueller. 1999. "Routine Activities and Sexual Harassment in the Workplace." Work and Occupations 26:21-49.

Dobbin, Frank, and John R. Sutton. 1998. "The Strength of a Weak State: The Employment Rights Revolution and the Rise of Human Resources Management Divisions." American Journal of Sociology 104:441-76.

Dobbin, Frank, John R. Sutton, John W. Meyer, and W. Richard Scott. 1993. "Equal 


\section{American Journal of Sociology}

Opportunity Law and the Construction of Internal Labor Markets." American Journal of Sociology 99:396-427.

Dolkart, Jane L., and E. Lynn Malchow. 1987. "Sexual Harassment in the Workplace: Expanding Remedies." Tort and Insurance Law Journal 23:181.

Domenick, Debra. 1999. "Title VII: How Recent Developments in the Law of Sexual Harassment Apply with Equal Force to Claims of Racial Harassment." Dickinson Law Review 103:765-801.

Ecabert, Gayle. 1987. "An Employer's Guide to Understanding Liability for Sexual Harassment under Title VII: Meritor Savings Bank v. Vinson." University of Cincinnati Law Review 55:1181-1206.

Edelman, Lauren B. 1992. "Legal Ambiguity and Symbolic Structures: Organizational Mediation of Civil Rights Law." American Journal of Sociology 97:1531-76.

- 2002. "Legality and the Endogeneity of Law." Pp. 187-203 in Legality and Community: On the Intellectual Legacy of Philip Selznick, edited by Robert A. Kagan, Martin Krygier, and Kenneth I. Winston. Lanham, Md.: Rowman \& Littlefield.

Edelman, Lauren B., Steven E. Abraham, and Howard S. Erlanger. 1992. "Professional Construction of the Law: The Inflated Threat of Wrongful Discharge." Law and Society Review 26:47-84.

Edelman, Lauren B., Christopher Uggen, and Howard S. Erlanger. 1999. "The Endogeneity of Legal Regulation: Grievance Procedures as Rational Myth." American Journal of Sociology 105:406-54.

Edwards, Richard. 1979. Contested Terrain: The Transformation of the Workplace in the Twentieth Century. New York: Basic Books.

Fligstein, Neil. 1990. The Transformation of Corporate Control. Cambridge, Mass.: Harvard University Press.

- 2001. The Architecture of Markets: An Economic Sociology of Twenty-FirstCentury Capitalist Societies. Princeton, N.J.: Princeton University Press.

Friedson, Eliot. 1975. Doctoring Together: A Study of Professional Social Control. New York: Elsevier Science.

Gallup Organization. 1991. Gallup Monthly Poll No. 313. Princeton, N.J.: Gallup Organization.

Gery, Gloria J. 1977. "Equal Opportunity: Planning and Managing the Process of Change." Personnel Journal 56:184-203.

Gordon, David M., Richard Edwards, and Michael Reich. 1982. Segmented Work, Divided Workers. London: Cambridge University Press.

Gruber, James E. 1998. "The Impact of Male Work Environments and Organizational Policies on Women's Experiences of Sexual Harassment." Gender and Society 12: 301-20.

Gutek, Barbara R., Aaron Groff Cohen, and Alison M. Konrad. 1990. "Predicting Social-Sexual Behavior at Work: A Contact Hypothesis." Academy of Management Journal 33:560-77.

Guthrie, Doug, and Louise Marie Roth. 1999. "The State, Courts, and Maternity Policies in U.S. Organizations: Specifying Institutional Mechanisms." American Sociological Review 64:41-63.

Haberman, Clyde. 1980. "City Agencies to Set Up Policies on Sexual-Harassment Charges." New York Times, December 28.

Harvard Law Review. 1984. "Sexual Harassment Claims of Abusive Work Environment under Title VII." Harvard Law Review 97:1149-67.

Hauck, Vern E. 1999. Arbitrating Sex Discrimination Grievances. Westport, Conn.: Quorum Books.

Hoover's Directory of Human Resources Executives. 1996. Austin: Reverence Press.

Hoyman, Michele, and Ronda Robinson. 1980. "Interpreting the New Sexual Harassment Guidelines." Personnel Journal 59 (12): 996-1000. 


\section{Legal Compliance}

Jacobs, Sanford L. 1985. "Changes in Employment Laws Can Trap Unwary Companies." Wall Street Journal, February 4.

Jensen, Michael C., and William H Meckling. 1976. "Theory of the Firm: Managerial Behavior Agency Cost and Ownership Structure." Journal of Financial Economics 3:305-60.

Kalbfleisch, J. D., and R. L. Prentice. 1980. The Statistical Analysis of Failure Time Data. New York: Wiley.

Kalleberg, Arne L., Peter V. Marsden, Howard E. Aldrich, and James W. Cassell. 1990. "Comparing Organizational Sampling Frames." Administrative Science Quarterly $35: 658-88$.

Kalleberg, Arne L., and Mark E. Van Buren. 1996. "Is Bigger Better? Explaining the Relationship between Organization Size and Job Rewards." American Sociological Review 61:47-66.

Kauppinen-Toropainen, K., and James E. Gruber. 1993. "Antecedents and Outcomes of Woman-Unfriendly Experiences." Psychology of Women Quarterly 17:421-56.

Kelly, Erin, and Frank Dobbin. 1998. "How Affirmative Action Became Diversity Management: Employer Response to Antidiscrimination Law, 1961-1996." American Behavioral Scientist 41:960-84.

Kochan, Thomas A., Harry C. Katz, and Robert B. McKersie. 1986. The Transformation of American Industrial Relations. New York: Basic Books.

Kronenberger, George K., and David L. Bourke. 1981. "Effective Training and the Elimination of Sexual Harassment." Personnel Journal 60:879-82.

Lawrence, Paul R., and Jay W. Lorsch. 1967. "Differentiation and Integration in Complex Organizations." Administrative Science Quarterly 12:1-47.

Leicht, Kevin T., and Mary L. Fennell. 1996. "Gender Representation in Corporate Law: Normative and Coercive Effects on the Structure of Corporate Legal Departments." Paper presented at the annual meeting of the American Sociological Association, New York.

Lincoln, James R., and Arne L. Kalleberg. 1985. "Work Organization and Workforce Commitment: A Study of Plants and Employees in the U.S. and Japan." American Sociological Review 50:738-60.

Linenberger, Patricia, and Timothy J. Keaveny. 1981a. "Sexual Harassment: The Employer's Legal Obligations." Personnel 58:60-68.

- 1981b. "Sexual Harassment in Employment." Human Resource Management 20:11-17.

Lowin, Aaron, William J. Hrapchak, and Michael J. Kavanaugh. 1969. "Consideration and Initiating Structure: An Experimental Investigation of Leadership Traits." Administrative Science Quarterly 14:238-53.

Machlowitz, David S., and Marilyn M. Machlowitz. 1987. "Preventing Sexual Harassment." American Bar Association Journal 73:78.

MacKinnon, Catharine A. 1979. Sexual Harassment of Working Women. New Haven, Conn.: Yale University Press.

March, James G., and Herbert A. Simon. 1958. Organizations. New York: Wiley.

Marino, Kenneth. 1980. "Conducting an Internal Compliance Review of Affirmative Action." Personnel 57:24-34.

McIntyre, Douglas I., and James C. Renick. 1982. "Protecting Public Employees from Sexual Harassment.” Public Personnel Management Journal 11:282-92.

Meyer, John W., and Brian Rowan. 1977. "Institutionalized Organizations: Formal Structure as Myth and Ceremony." American Journal of Sociology 83:340-63.

Michigan Law Review. 1978. "Sexual Harassment and Title VII: The Foundation for the Elimination of Sexual Cooperation as an Employment Condition." Michigan Law Review 76:1007-35.

Milliken, Frances J., Luis Martins, and Hal Morgan. 1998. "Explaining Organizational 


\section{American Journal of Sociology}

Responsiveness to Work-Family Issues: The Role of Human Resource Executives as Issue Interpreters." Academy of Management Journal 5:580-92.

Nelson, Robert L., and Laura Beth Nielsen. 2000. "Cops, Counsel, and Entrepreneurs: Constructing the Role of Inside Counsel in Large Corporations." Law and Society Review 34:457-94.

Ocasio, William, and Hyosun Kim. 1999. "The Circulation of Corporate Control: Selection of Functional Backgrounds of New CEOs in Large U.S. Manufacturing Firms, 1981-1992." Administrative Science Quarterly 44:532-62.

Renick, James C. 1980. "Sexual Harassment at Work: Why It Happens What to Do About It." Personnel Journal 59:658-63.

Rhode, Deborah L. 1992. "Gender, Race, and the Politics of Supreme Court Appointments: The Import of the Anita Hill/Clarence Thomas Hearings." Southern California Law Review 65:1459-66.

Robin, Donald P. 1967. "An Input-Output Model of Employee Behavior.” Academy of Management Journal 10:257-68.

Rowe, Mary P. 1981. "Dealing with Sexual Harassment." Harvard Business Review 59 (3): 42-45.

Safran, Claire. 1976. "What Men Do to Women on the Job: A Shocking Look at Sexual Harassment." Redbook, November.

Saguy, Abigail. 2003. What Is Sexual Harassment: From Capitol Hill to the Sorbonne. Berkeley and Los Angeles: University of California Press.

Sarfatti-Larsen, Magali. 1977. The Rise of Professionalism: A Sociological Analysis. Berkeley: University of California Press.

Sawyer, Sandra, and Arthur A. Whatley. 1980. "Sexual Harassment: A Form of Sex Discrimination." Personnel Administrator 25 (1): 36-39.

Schaeffer, Ruth G. 1975. Nondiscrimination in Employment, 1973-1975: A Broadening and Deepening National Effort. New York: Conference Board.

Schultz, Vicki. 2003. "The Sanitized Workplace." Yale Law Journal 112:2061-2193.

Scott, William G. 1968. "Technology and Organization Government: A Speculative Inquiry into the Functionality of Management Creeds." Academy of Management Journal 11:301-13.

Selznick, Philip. 1957. Leadership in Administration: A Sociological Interpretation. New York: Harper \& Row.

1969. Law, Society and Industrial Justice. New York: Russell Sage.

Shah, Diane K., and Susan Agrest. 1979. "A Steno Who Said 'NO!"” Newsweek, April 30 .

Somers, Patricia A., and Judith Clementson-Mohr. 1979. "Sexual Extortion in the Workplace." Personnel Administrator 24 (4): 23-28.

Spann, Jeri. 1990. "Dealing Effectively with Sexual Harassment: Some Practical Lessons from One City's Experience." Public Personnel Management 19:53-82.

Starr, Paul. 1982. The Transformation of American Medicine. New York: Basic.

Stinchcombe, Arthur L. 1965. "Social Structure and Organizations." Pp. 142-93 in Handbook of Organizations, edited by James G. March. Chicago: Rand McNally.

Stryker, Robin. 2000. "Legitimacy Processes as Institutional Politics: Implications for Theory and Research in the Sociology of Organizations." Research in the Sociology of Organizations 17:179-223.

Sturm, Susan. 2001. "Second Generation Employment Discrimination: A Structural Approach." Columbia Law Review 101:459-568.

Sutton, John R., and Frank Dobbin. 1996. "The Two Faces of Governance: Responses to Legal Uncertainty in American Firms, 1955-1985." American Sociological Review 61:794-811.

Turner, Ronald. 1990. "Employer Liability under Title VII for Hostile Environment Sexual Harassment by Supervisory Personnel: The Impact and Aftermath of Meritor Savings Bank." Howard Law Journal 33:1-52. 


\section{Legal Compliance}

Van de Ven, Andrew H., Douglas Polley, Raghu Garud, and S. Venkataraman. 1999. The Innovation Journey. New York: Oxford University Press.

Verespej, Michael A. 1991. "Longer Dockets, Deep Pockets: A Political Retreat on Civil Rights Will Make Business Sitting Ducks for More Lawsuits." Industry Week, November 18.

Wymer, John F., III. 1983. "Compensatory and Punitive Damages for Sexual Harassment." Personnel Journal 62:181-84.

Zippel, Kathrin S. 2006. The Politics of Sexual Harassment: A Comparative Study of the United States, the European Union, and Germany. Cambridge: Cambridge University Press. 